\title{
YALE NATURAL RADIOCARBON MEASUREMENTS IV
}

EDWARD S. DEEVEY, L. J. GRALENSKI, and VÄINÖ HOFFREN

Geochronometric Lahoratory

Yale University, New Haven, Connecticut

Dates obtained since our last date list (Yale III*), and up to the end of 1958, are given here. All are based on duplicate measurements of $\mathrm{CO}_{2}$ in a proportional counter. Grateful acknowledgment is made to the National Science Foundation, which has supported our work through grant no. G-2278. Participation of Väinö Hoffren during 1956-1957 was made possible through an arrangement with the Geological Survey of Finland. The technical assistance of Julius Kovats has been invaluable. 
bunk River, near Kennebunk, Maine. A natural mold of a small pelecypod, probably Yoldia, was found in the overlying sandy silt. Modern roots had penetrated the sample but were removed by hand-picking under magnification. Coll. 1958 and subm. by A. L. Bloom, Yale University. Comment: this sample was believed to be driftwood, grounded on a sand bar and buried by marine sediment during the postglacial rise of sealevel in SW Maine, and was expected to date woody vegetation growing in a belt between the wasting glacier and the transgressing sea. Its modern age conflicts with this interpretation, as do the ecology and distribution of beech, but the possibility remains that the wood, like the rootlets, was intrusive.

\section{Y-609. Zella Island, Maine}

$\mathbf{5 3 1 0} \pm \mathbf{2 4 0}$

Wood fragments, 0.2 to $0.7 \mathrm{in}$. diam, 3 to 4 . $\mathrm{ft}$ below surface, underlying till and sand, Zella Island, Fish River Lake (68 $46^{\prime} 43^{\prime \prime} \mathrm{N}$ Lat, $46^{\circ} 45^{\prime} 50^{\prime \prime}$ W Long), Aroostook County, Maine. The overlying till, believed by the collector to be of Valders age, is continuous over the island, which is low and rather flat; hence its emplacement by solifluction in postglacial time is considered unlikely. Coll. 1958 and subm. by Gary McG. Boone, University of Western Ontario, London, Canada. Comment: the sample was small and the error is correspondingly large. Sample Y-610, though not collected by a geologist, was reliably reported to have come from the same stratigraphic position, and was measured as a check on the problematic date of Y-609. Since the dates agree, the inferred Valders age of the till is apparently disproved, but the implication that the regional glaciation was younger than ca. $5000 \mathrm{yr}$ cannot be accepted without further field work.

Y-610. Zella Island, Maine

$4760 \pm 100$

Beaver-gnawed sticks of Taxus canadensis (id. by W. L. Stern), 4 to $5 \mathrm{ft}$ below surface, in the same stratigraphic position and at the same locality as Y.609, but $8 \mathrm{ft}$ to E. Coll. "a few years ago" by Dana McNally, proprietor of hunting camps on Zella Island; subm. by Gary McG. Boone, University of Western Ontario, London, Canada. Comment: see Y-609.

\section{Y-156. Odiorne Point, New Hampshire $\quad 4190+70$}

White pine stump (id. by U. S. Forest Products Laboratory), part of the drowned forest at Odiorne Point $\left(43^{\circ} 02^{\prime} \mathrm{N}\right.$ Lat, $70^{\circ} 44^{\prime} \mathrm{W}$ Long), near Portsmouth, New Hampshire, described by Lyon and Goldthwait (1934). The tree grew with its hase well below high tide, $2.4 \mathrm{ft}$ above low water in July, 1931. Sample no. OP-5; coll. 1931 and subm. 1952 by C. J. Lyon, Dartmouth College, Hanover, New Hampshire. Comment: other dates for drowned forests along the eastern United States coast are: L-118, 4150 \pm 200 , from Sagadahoc Bay, Maine (Lamont II) ; W-396, $2980 \pm 180$, from Wells, Maine (USGS IV) ; C.943, $2830 \pm 220$, from Pelham Bay, New York (Chicago V). An unpublished Nova Scotia date of $4200 \pm 200$ for a stump at Avonport, N. S., is similar (Cameron, 1956). From the pollen stratigraphy of coastal marshes (e.g. Deevey, 1948), and from such data as those from the Boylston Street fishweir (Johnson and others, 1942; Johnson (ed.), 1949) ) it has long been evident that sealevel has been rising along the entire coast for several thousand years. The radiocarbon dates, since they come from trees growing a few feet helow present sealevel, suggest that most of the recorded rise was completed, 
at least in the Gulf of Maine, by about 4000 B.P. The date of C-943 has been used by Fairbridge (1958) as an argument for a "Pelham Bay emergence" about 2800 B.P., but it has not been shown that the event dated there was in fact an emergence of the land after a previous period of higher sealevel. Data from the Gulf of Maine are not necessarily in conflict with Fairbridge's interpretation, however, since they come from a region subject to isostatic as well as to eustatic delevelling.

\section{Totoket series, Connecticut}

Gyttja from horings made with a Livingstone borer in the lower part of Totoket bog $\left(41^{\circ} 20^{\prime} 00^{\prime \prime} \mathrm{N}\right.$ Lat, $72^{\circ} 49^{\prime} 49^{\prime \prime}$ W Long), North Branford, Connecticut. The pollen stratigraphy was published by Leopold (1956) ; new borings in 1956, with unpublished pollen stratigraphy by Deevey, gave radiocarbon dates published in Yale III, but were unsatisfactory on stratigraphic grounds. More borings were made at arbitrary grid intersections in 1957, and a bathymetric map of the former lake was prepared; the pollen stratigraphy allows satisfactory correlation with Leopold's zone houndaries but will be studied in more detail before publication. The importance of the deposit consists in its record of a pre-Two-Creeks climatic oscillation of the Bölling type, the first reported from North America; see Deevey, 1958, for discussion of pollen stratigraphy of eastern North America. Coll. 1957 by E. S. Deevey and Elizabeth Guillard, Yale University.

Y-504. Totoket, zone A-4

$10,440 \pm 200$

Gyttja from pollen zone A-4 (upper part of the Durham spruce-pollen zone), 4.70 to $4.80 \mathrm{~m}$ in meter-sample $2 \mathrm{~L}$, boring $\mathrm{ED}-2$, coll. with 2 -in. Livingstone borer. Comment: the date is in excellent agreement with Y-447e $(10,480 \pm 140$, Yale III) from the same zone in Red Maple Swamp, near New London, Connecticut. The 1956 Totoket sample (Y-446f, 12,080 \pm 300 , Yale III) is too old and must be rejected. The 1956 Totoket sample from the next higher zone, B (Y-446g, 9650 \pm 90 , Yale III) must likewise be rejected.

Y-503. Totoket, zone A-2

$11,590 \pm 200$

Clay-gyttja from pollen zone A-2 (lower part of Durham spruce-pollen zone), 4.95 to $5.05 \mathrm{~m}$ in meter-sample 2L, boring ED-2, the same metersample as Y-504. Comment: four of the five dates from this zone in southern Connecticut are in reasonable agreement (Y-285, 13,550 \pm 460, Yale II, from Totoket; Y-447d, 13,290 \pm 120, Yale III, from Red Maple Swamp; W-46, $12,700 \pm 280$, USGS I, from Durham). The new date seems slightly too young, but the 1956 Totoket sample (Y-446d, 14,790 \pm 160 , Yale III) is definitely too old and must be rejected with the other 1956 dates. The average age of zone A-2 is considered to be about $12,780 \mathrm{yr}$.

Y-505. Totoket, zone T-3

$12,350 \pm 400$

Clay-gyttja from pollen zone T-3 (younger herb-pollen zone), 6.73 to $6.95 \mathrm{~m}$ in meter-sample L3, boring ED-3, coll. with 11/2-in. Livingstone borer. Comment: this sample, though consistent with the other 1957 dates, seems slightly too young in comparison with all available information. The $22-\mathrm{cm}$ length of sample needed in this boring is undesirably great, and probably 
weighted the radiocarbon measurement in favor of younger carbon. A date of the order of $13,000 \mathrm{yr}$ is more reasonable, and is permissible statistically.

Y-502. Totoket, zone T-2

$13,280 \pm 420$

Clay-gyttja from pollen zone T-2 (pre-Durham spruce-pollen zone), 5.46 to $5.64 \mathrm{~m}$ in meter-sample $3 \mathrm{~L}$, boring ED-2, coll. with 2-in. Livingstone borer. Comment: this sample was $18 \mathrm{~cm}$ long and may be slightly too young for the same reason given for Y-505. A modal age of $13,500 \mathrm{yr}$ is probable, but the date obtained is in excellent agreement with the dates for the Bölling zone at Gaterslebener See (H88-74, 13,250 \pm 280 ; H106-89, 12,700 \pm 320, Heidelberg I). Bölling dates at Usselo, Netherlands, are slightly younger: Gro-927, $12,355 \pm 170$; Gro-1104, 12,300 \pm 100 (Groningen II). The 1956 date for the underlying zone (T-1) at Totoket (Y-446a, 15,090 \pm 160 , Yale III), though not impossible, should probably be rejected with the others of that series.

\section{Y-460. Kings Ferry, New York}

$11,410 \pm 410$

Spruce wood (id. by Clair A. Brown) from basal clay stratum, associated with mastodon (Mammut americanum) skeleton at Myles L. Colgan farm, Kings Ferry ( $42^{\circ} 40^{\prime} \mathrm{N}$ Lat, $76^{\circ} 36^{\prime} \mathrm{W}$ Long), near Ledyard, Cayuga County, New York. The excavation was made by bulldozer through a small, poorly drained depression; reconstruction of the section by Brown showed $4 \mathrm{ft}$ of peaty muck overlying $2 \mathrm{ft}$ of gray clay containing mastodon bones and a rich flora and snail fauna. The section overlies sand and gravel. The fossil flora appears to record a boreal coniferous forest with mosses, but includes Ulmus and Acer as well as Picea and Abies; it is to be described by Brown. Coll. 1955 by C. A. Brown, Louisiana State University, Baton Rouge; subm. by W. A. Ritchie, New York State Museum, Albany. Comment: as the section was exposed by bulldozer, the association of such warm-climate trees as elm and maple with the mastodon must remain doubtful. The spruce wood, however, was definitely in situ in the basal clay layer, beside a mastodon tusk. Its date seems reasonable as that of one of the last mastodons in eastern United States; compare M-66, $9600 \pm 500$ (Michigan I) for wood underlying the Orleton Farms mastodon, Madison County, Ohio, and L-231, 10,890 \pm 200 , for peat at a mastodon site in Sussex County, New Jersey (Lamont IV). See Williams (1957) for review of other mastodon dates. The implication of closed forest in south-central New York during Two Creeks time is also of interest; compare Y $-503,11.590 \pm 200$, and Y-504, 10,440 \pm 200 (this paper) for sprucepollen zones bracketing this interval at Totoket in southern Connecticut.

\section{Y.479. Marsh, Pennsylvania}

$12,690 \pm 220$

Coarse sand and clay in a pollen-stratigraphic section at The Marsh $\left(40^{\circ}\right.$ $07^{\prime} \mathrm{N}$ Lat, $75^{\circ} 47^{\prime} \mathrm{W}$ Long), Chester County, Pennsylvania. The level, 56 to 62 in. below surface, is that of zone F-3, containing the first maximum of arboreal pollen, believed (Martin, 1958) to be mainly redeposited and not contemporary with the sediment; the latter is interpreted as alluvium and colluvium formed at a glacial maximum, probably the Wisconsin maximum. Sample no. 3 ; coll. 1956 and subm. by P. S. Martin, Geochronology Laboratories, University of Arizona, Tucson. Comment: the locality was never gla- 
ciated and lies $54 \mathrm{mi}$ beyond the outermost $\mathrm{W}$ isconsin drift border. The pollen, in those older zones that are believed to be free from redeposited contaminants, is dominantly of nonarboreal plants, including several of arctic distribution, and these zones are therefore interpreted as full-glacial. The date does not disprove this interpretation, as it gives an age approximately that of the Port Huron readvance (ca. 13,000 yr; cf. Flint and Rubin, 1955, and the date of Y-240, 12,800 \pm 250 , Yale III), and of pollen zone T-3 in southern Connecticut (Deevey, 1958; see Y-505, 12,350 \pm 400 , this paper), though it was expected to be older. Redeposition in such a sediment may well have introduced foreign carbon along with anomalous pollen grains.

\section{Y-473-1. Clarksville, Ohio}

$>37,000$

Wood imbedded in till, excavated by dragline in a gravel pit from beneath outwash filling a valley cut in the Cuba moraine, $1 \mathrm{mi}$ NE of Clarksville (39 $241 / 2^{\prime} \mathrm{N}$ Lat, $83^{\circ} 85^{\prime} \mathrm{W}$ Long), Clinton County, Ohio. The outwash, ca. $20 \mathrm{ft}$ thick, is similar to other "oldest late Wisconsin" drift in being capped by 18 in. of silt (loess?) through which a 50-in. soil has developed. The underlying till, first suspected (Forsyth, private communication) to antedate the "classic" or late Wisconsin glaciation, was later suspected to belong to the Cuba moraine system of late Wisconsin age, the outermost Wisconsin drift in this part of Ohio. Coll. 1956 and subm. by J. L. Forsyth, Ohio Geological Survey, Columbus. Comment: although several dated samples from Ohio fall into this "older group" ( $>32,000 \mathrm{yr}$; Goldthwait, 1958), the others were all clearly below the latest till and are believed to date from a nonglacial interval younger than Sangamon and older than "classic" Wisconsin. This is the first such specimen to occur in till. Assignment of the till to the "classic" Wisconsin, considered unlikely on first examination, is made more unlikely by the date of the wood.

\section{Y-448. Cuba, Ohio}

$18,500 \pm 420$

Picea $\log \left(\mathrm{id}\right.$. by G. W. Burns) in till $\left(39^{\circ} 21^{\prime} \mathrm{N}\right.$ Lat, $83^{\circ} 51^{\prime} \mathrm{W}$ Long), $1.1 \mathrm{mi}$ SE of Cuba, Washington township, Clinton County, Ohio. The excavation, for a farm pond $18 \mathrm{ft}$ deep, was made on the outer face of the outermost Wisconsin terminal moraine in the only till body known to have been deposited in this moraine. The ecologic and geologic implications are discussed by Burns (1958) and Goldthwait (1958). Coll. 1956 and subm. by R. P. Goldthwait, Ohio State University, Columbus. Comment: see Y-450.

\section{Y-449. Columbus, Ohio}

$$
23,000 \pm 850
$$

Abies $\log$ (id. by G. W. Burns) in till at $15 \mathrm{ft}$ depth in excavation for Bell Telephone Co. Bldg., 4th and Long Sts. (39 $571 / 2^{\prime} \mathrm{N}$ Lat, $83^{\circ} 00^{\prime} \mathrm{W}$ Long), Columbus, Franklin County, Ohio. The sample was scraped by bulldozer but was certainly imbedded in till, near contact of till with underlying gravel. Coll. 1956 and subm. by R. P. Goldthwait, Ohio State University, Columbus. Comment: see Y-450.

Y.450. Darrtown, Ohio

Picea $\log$ (id. by G. W. Burns) from $40 \mathrm{ft}$ depth in a $65-\mathrm{ft}$ exposure of till, SE bank of Fourmile Creek cut, $1.5 \mathrm{mi}$. SW of Darrtown $\left(39^{\circ} 29^{\prime} \mathrm{N}\right.$ Lat, $84^{\circ} 41^{\prime} \mathrm{W}$ Long), Milford township, Butler County, Ohio. Tree-ring measure- 
ments on this specimen (Burns, 1958) show progressive diminution of growth before death; the geologic data on the site are discussed by Goldthwait (1958). Coll. 1956 and subm. by R. P. Goldthwait, Ohio State University, Columbus. Comment: these three samples confirm the picture (Flint, 1955a; Flint and Rubin, 1955; Goldthwait, 1958) of a glacial advance that invaded Ohio beginning about $25,000 \mathrm{yr}$ ago, overwhelmed spruce forests successively during its southward advance (at Columbus 23,000 yr ago; see Y-449, which is to be compared with W-188, $23,000 \pm 800$, USGS II, from Sidney), and reached its outer limits 18,000 to $20,000 \mathrm{yr}$ ago. Retreat of the western or Miami lobe may have begun earlier than that of the eastern or Scioto lobe; compare W-92 (19,980 \pm 500 , USGS I) with W-91 (18,050 \pm 400 , USGS I), the latter now essentially duplicated by Y-448. The date of Y-450 implies local readvance of the western lobe about 15,600 yr ago.

\section{Y-526. Northern Lights, Ohio}

$11,480 \pm 160$

Wood from postglacial kettle deposit at Northern Lights shopping center $\left(40^{\circ} 11 / 2^{\prime} \mathrm{N}\right.$ Lat, $82^{\circ} 581 / 2^{\prime} \mathrm{W}$ Long), Cleveland Ave., Columbus, Franklin County, Ohio. The wood, gnawed by beaver and accompanied by a skull of Castoroides, probably occurred in lower 5 - $\mathrm{ft}$ peat-and-gyttja layer, overlain by $3 \mathrm{ft}$ of peat and underlain by calcareous clay and then by till; the section was made by bulldozer at a slightly deeper part of the kettle, and checked later by soil sampler. Coll. 1957 and subm. by Jane L. Forsyth, Ohio Geological Survey, Columbus.

\section{Y-488. Lake Butte des Morts, Wisconsin}

$11,280 \pm 100$

Wood from varved clay, "perhaps reworked but older than the surface till of Valders [age]", exposed between Appleton and Menasha (44. $14^{\prime} \mathrm{N}$ Lat, $82^{\circ} 27^{\prime}$ W Long), Wisconsin, on the eastern shore of Little Lake Butte des Morts. "Appears flattened by pressure"; coll. and subm. to the Chicago laboratory as C-419 by F. T. Thwaites, 41 N. Roby Road, Madison, Wisconsin. This is a portion of the original specimen, subm. by F. Begemann through R. F. Flint, Yale University. Comment: the Chicago date, $6401 \pm 230$ (Chicago I), has always been anomalous (Flint and Deevey, 1951), and there no longer seems to be reason to doubt that the sample is of Valders age.

Y-572. Woodville, Wisconsin

$30,650 \pm 1640$

Spruce (id. by U. S. Forest Products Laboratory, Madison, Wisconsin) fragments from till, exposed in a railroad cut, NW 1/4 Sec. 35, T 29 N, R 16 W $\left(44^{\circ} 57^{\prime} \mathrm{N}\right.$ Lat, $92^{\circ} 17^{\prime} \mathrm{W}$ Long $)$, near Woodville, St. Croix County, Wisconsin. Coll. 1915 by Samuel Weidman, Wisconsin Geological Survey (W. G. S. catalogue no. 24698); the wood was believed by him to be the debris of a forest overridden by glacial advance. Subm. 1957 by R. F. Flint, Yale University. Comment: because of its location in an area between the Valders and Mankato glacial lobes, the sample was expected to date from either the Valders or the Mankato glacial advances. As it is much older than either of these episodes, the inclosing till is probably older also.

\section{Pascagoula series, Mississippi}

Wood fragments from submarine core $7796-\mathrm{H}$, Gulf Research and Development Co. $\left(29^{\circ} 50^{\prime} 23^{\prime \prime}\right.$ N Lat, $88^{\circ} 07^{\prime} 48^{\prime \prime}$ W Long $), 25$ nautical mi S of 
Dauphin Island, Alabama, 35 nautical mi E of Chandeleur Islands, Louisiana, on the central continental shelf off Pascagoula, Mississippi, 20 fathoms depth. The wood occurred at 7 to $12 \mathrm{in}$. and at 18 to $20 \mathrm{in}$. below the ocean floor in a peaty clay, part of the series of postglacial deposits that overlie a weathered clay layer. The latter is inferred to have been formed on land, and is represented by at least $8 \mathrm{ft}$ of clay underlying the wood in core $7796-\mathrm{H}$. The postglacial deposits of the region include well-sorted fine white quartz sand and a shell unit, in addition to the silts and clays containing wood that are interpreted as estuarine or swamp deposits; the sand, shell, and wood-bearing silt and clay are believed to be different facies, rather than sequential units. Hence the age of the wood should be approximately the same as that of the shells and of the sand, and should mark the time of marine transgression when the core locality was at or near sealevel and at or near the shoreline. Coll. 1955; subm. by Ben B. Cox, Gulf Research and Development Co., Pittshurgh 30, Pennsylvania.

Y-425. Wood, 7 to 12 in.

Y-426. Wood, 18 to 20 in.

$10,120 \pm 120$

Comment: the dates arree closely with similar determinations of $\pm \mathbf{1 7 0}$ of the -120-ft level in the Gulf of Mexico and elsewhere (Shepard and Suess, 1956; Godwin, Suggate, and Willis, 1958). Samples 0-45, 10,700 \pm 220 , and $0-99,11,200 \pm 240$ (Humble II), are particularly relevant as dating positions of -150 and -165 ft, respectively. However, these positions of the sealevel during eustatic rise are arrived at by correcting for downwarp in the Mississippi delta, and are not necessarily more exact than the radiocarbon dates, many of which are based on shell samples. Sample L-175B, $9750 \pm 550$ (Lamont III) was wood from -120 to $-135 \mathrm{ft}$, a position that was not corrected for downwarp. The work of Shepard and Moore (1955) contains several unnumbered and otherwise unpublished dates by the Magnolia Petroleum Co., including one of wood $(9800 \pm 350)$ from $-90 \mathrm{ft}$ in San Antonio Bay near Rockport, Texas.

\section{B. Western North America}

\section{Y-571. Hakon County, South Dakota $\quad 29,310 \pm 1400$}

Wood from a partly mineralized log, 12 to 14 in. diam, found in a borrow pit ca. $10 \mathrm{ft}$ below ground surface, sec. $21, \mathrm{~T} 8 \mathrm{~N}, \mathrm{R} 24 \mathrm{E}\left(44^{\circ} 43^{\prime} \mathrm{N}\right.$ Lat, $101^{\circ} 13^{\prime}$ W Long), Haakon County, South Dakota. The log was partly imbedded in coarse sand, possibly proglacial, carried "from an early glacial extension up the Cheyenne River" (letter from G. A. Avery, 10 April 1957). Coll. 1956 by Frank Kocer; subm. by G. A. Avery, Soil Conservation Service, Huron, South Dakota, through R. F. Flint. Comment: the sample was routinely acid-washed but not treated with alkali; there is a possibility of contamination by humus younger than the specimen. If valid, and if the inclosing sand is proglacial, the date records a glacial maximum.

Y-595. Hurley, South Dakota

$12,760 \pm 120$

Picea or Larix (id. by W. L. Stern) from outwash, $32 \mathrm{ft}$ below surface in a well on T. H. Newhauer farm, SW 1/4 sec. 15 , T $98 \mathrm{~N}, \mathrm{R} 53 \mathrm{~W}\left(43^{\circ} 19^{\prime} \mathrm{N}\right.$ 
Lat, $97^{\circ} 05^{\prime} \mathrm{W}$ Long), near Hurley, South Dakota. The surface outwash was mapped by R. F. Flint (1955, pl. 1) as Mankato in age; the bore hole penetrated outwash through the entire distance. Subm. by G. A. Avery, Soil Conservation Service, Huron, South Dakota, through R. F. Flint. Comment: this Mankato date agrees with that from Parker, South Dakota (Y-452, 12,330 士 180, Yale III), and with similar dates from Iowa (C-596, 11,952 \pm 500 ; C-653, 12,200 \pm 500 , Chicago III).

\section{Y-313. Black Diamond Bog, Washington}

$5390 \pm 60$

Fibrous peat from 0 to $3 \mathrm{in}$. below layer of volcanic ash, immediately above maximum of Douglas fir pollen, $2.3 \mathrm{~m}$ below bog surface at Station 2, Black Diamond Bog, sec. 2, 35, T $21 \mathrm{~N}, \mathrm{R} 6 \mathrm{E}\left(47^{\circ} 20^{\prime} \mathrm{N}\right.$ Lat, $112^{\circ} 00^{\prime} \mathrm{W}$ Long), King County, near Tacoma, Washington. A pollen diagram from an older boring was published by Hansen (1941); the new boring was one of four in which multiple Hiller samples were taken below the ash layer at widely separated localities on the bog. The ash layer is attributed to the eruption of Glacier Peak, ca. $90 \mathrm{mi} \mathrm{NE}$, and occurs in more than 200 bogs over an area of ca. 180,000 mi² (Rigg and Gould, 1957). Coll. 1955 and subm. by H. P. Hansen, Oregon State College, Corvallis. Comment: in eastern Washington, where the pollen diagrams are more easily zoned than in the Puget lowland, the Glacier Peak ash layer coincides with the maximum of chenopod and composite pollen, suggesting a date close to that of the postglacial thermal maximum, or ca. $6000 \mathrm{yr}$ (Hansen, 1947). Two other dates from peat below the ash in Puget lowland bogs are relevant: L-269B, $7000 \pm 200$, from Moss Lake, and L-296C, 6500 \pm 200 , from Covington Bog (Lamont III). The Black Diamond Bog date is in substantial agreement and tends to bracket Hansen's estimate; it may be younger than the other two because the sample was a composite one, or because the ash at this locality was partly redeposited by water after subaerial deposition. However, there is no independent evidence of redeposition at this locality, as there is at others (Rigg and Gould, 1957).

\section{Rancho La Brea series, California}

Wood from increment cores bored in trunk of tree excavated in 1913 at Pit 3, Section D-2, 4- to 12-ft depth, Rancho La Brea, Los Angeles (34. $03^{\prime}$ $45^{\prime \prime} \mathrm{N}$ Lat, $118^{\circ} 21^{\prime}$ W Long), California. Bones of typical, extinct La Brea animals were packed in the lar around the upright trunk, which was rooted in soil beside and below the tar. An outer rind and a rotted inner core were tarimpregnated, while the rest of the wood was sound and apparently unaltered. Two cores were taken, one at 33 in. above the bottom of the trunk, the other 11.5 in. higher; the sound wood from each core was ground in a mortar, and portions of each sample were washed in xylol before combustion to remove traces of tar. Subm. by Hildegarde Howard, Los Angeles County Museum.

Y-354A. Rancho La Brea, no. 1, untreated 14,500 \pm 210

Untreated portion of sample no. 1, a 2 -in. core taken 33 in. above base of trunk.

Y.354B. Rancho La Brea, no. 1, xylol-washed $15,390 \pm 230$

Xylol-washed portion of sample no. 1 . 
Y-355A. Rancho La Brea, no. 2, untreated $14,110 \pm 420$

Untreated portion of sample no. 2, a 2 -in. core taken 11.5 in. above sample no. 1.

Y-355B. Rancho La Brea, no. 2, xylol-washed $13,890 \pm 280$

Xylol-washed portion of sample no. 2.

Comment: the four separate measurements are not significantly different from each other, showing that impregnation of the wood by tar containing ancient carbon was not so serious as had been feared. However, the test does not show whether or not the obviously tar-soaked wood would give a false date. A date of ca. 14,500 yr for the famous La Brea assemblage of extinct mammals and birds is not unreasonable, though much higher estimates have been widely quoted. Douglas (1952) cited two unpublished CalTech dates, 16,250 \pm 2000 and $16,400 \pm 2000$, for wood subm. by Chester Stock. The present sampling, of course, represents only one of the 20 or more pits excavated at Rancho La Brea.

\section{Searles Lake series, California}

Organic mud samples from the Parting Mud layer, $78 \mathrm{ft} 10 \mathrm{in}$. to $90 \mathrm{ft}$ 7 in. below surface in Lower Structure Well X-20, made by American Potash and Chemical Co. in the dry bed of Searles Lake $\left(35^{\circ} 46^{\prime} \mathrm{N}\right.$ Lat, $117^{\circ} 20^{\prime} \mathrm{W}$ Long), near Trona, California. The stratigraphy of the salt and mud deposits of the basin is discussed by Flint and Gale (1958) on the basis of a large number of radiocarbon dates obtained by several laboratories. The overlying Upper Salt body is postpluvial; the Parting Mud records a high lake level lasting from about 24,000 to about 11,000 B.P.; the Lower Salt records an interpluvial interval from about 31,000 to about 24,000 B.P.; the Bottom Mud, the bottom of which has not been reached, records a pluvial time older than 31,000 yr. The four samples, submitted as 8-in. lengths of a drill-core 9 in. in diameter, were composed mainly of carbonates, which were separated by acidification from the organic carbon fractions, and both fractions were dated. Coll. 1957 and subm. by D. E. Garrett, Research Manager, American Potash and Chemical Co., through R. F. Flint.

Y-574a. Searles Lake, top, carbonate $\quad 11,810 \pm 140$ Top 8 in. of Parting Mud, $78 \mathrm{ft} 10 \mathrm{in}$. to $79 \mathrm{ft} 6 \mathrm{in}$., carbonate fraction.

Y-574b. Searles Lake, top organic

$10,700 \pm 130$

Organic carbon remaining after acidification of Y-574.

Y-575a. Searles Lake, one-third down, carbonate

$12,420 \pm 160$

From $81 \mathrm{ft} 8.5 \mathrm{in}$. to $82 \mathrm{ft} 4 \mathrm{in}$., carbonate fraction.

\section{Y-575b. Searles Lake, one-third down, organic}

$12,730 \pm 210$

Organic carbon remaining after acidification of Y-575.

\section{Y-576a. Searles Lake, two-thirds down, carbonate}

From $85 \mathrm{ft} 4$ in. to $86 \mathrm{ft} 2$ in., carbonate fraction.

$16,890 \pm 210$ 


\section{Y-576b. Searles Lake, two-thirds down, organic}

Organic carbon remaining after acidification of Y-576.

Y-577a. Searles Lake, bottom, carbonate

$22,350 \pm 1750$

Bottom 8 in. of Parting Mud, $89 \mathrm{ft} 11$ in. to $90 \mathrm{ft} 7 \mathrm{in}$., carbonate fraction.

\section{Y-577b. Searles Lake, bottom, organic}

$24,690 \pm 1070$

Organic carbon remaining after acidification of Y $\mathbf{5 7 7 .}$

Comment: the carbonate fractions were dated on the assumption that the modern reference carbonate should have 1.05 times the $\mathrm{C}^{14}$ activity of modern wood; this assumption, based on the fact that the $\mathrm{C}^{13}$ content of marine $\mathrm{CaCO}_{3}$ is 1.025 times that of wood, requires validation for inland waters and for $\mathrm{Na}, \mathrm{CO}$, for the dominant "salt" in the basin is trona. Our measurements of $\mathrm{C}^{13}$ in the trona show a small but apparently real enrichment over the limestone standard, and will form the basis of a separate paper. When calculated in this way, carbonate and organic fractions do not differ significantly in age, and the geochemical problems of the basin, though highly interesting and challenging, appear not to affect the equally interesting conclusions as to the pluvial history of Searles Lake. Flint and Gale (1958) should be consulted for a more complete list of relevant dates.

\section{South America}

\section{Estancia Viamonte series, Tierra del Fuego}

Compressed peat from a 7 - to $10-\mathrm{cm}$ layer between the second-oldest and third-oldest of three layers of till, exposed in seacliff $\left(54^{\circ} 03^{\prime} \mathrm{S}\right.$ Lat, $67^{\circ} 20^{\prime} \mathrm{W}$ Long), $29 \mathrm{~km} \mathrm{~S}$ of Estancia Viamonte, near Rio Grande, Tierra del Fuego, Argentina. The Pleistocene section described by Auer $(1956,1958)$ is $8.5 \mathrm{~m}$ thick, resting on Pliocene sandstone, beginning about $1.5 \mathrm{~m}$ above high-tide level, and consists of three layers of till; the peat is exposed at ca. $4 \mathrm{~m}$ above high-tide level, and there is a thin layer of limonite at ca. $7.4 \mathrm{~m}$, between the upper two layers of till. The peat may be in part transported; the pollen and megascopic fossils imply a nonglacial climate, not greatly different from today's. Coll. 1952 by R. T. Reynolds; subm. by Väinö Auer, Geological Institute, Helsinki University.

\section{Y.194. Estancia Viamonte 16}

Auer's sample 16.

Y-195. Estancia Viamonte 20

Another portion of the same peal layer; Auer's sample 20. Comment: the peat is the first surely interglacial deposit yet dated in South America.

Y.181. La Mision, Tierra del Fuego $\quad 7850 \pm 110$

Peaty gyttja from a 25-cm layer, the hottom of which is 8.70 to $8.80 \mathrm{~m}$ below the surface and 4.20 to $4.30 \mathrm{~m}$ below mean high tide, in a coastal hog at La Mision, Rio Grande $\left(53^{\circ} 43^{\prime} \mathrm{S}\right.$ Lat, $67^{\circ} 49^{\prime} \mathrm{W}$ Long), Tierra del Fuego, Argentina. The freshwater layer is underlain and overlain by marine clay layers, recording at least three rises of sealevel, the last of which reached at least $2 \mathrm{~m}$ above the present level; a layer of volcanic ash, identified by Auer 
(1956) as $0_{2}$ (third-oldest in the "late-glacial" sequence), associated with steppe-plant pollen zones, immediately overlies the dated gyttja. Postglacial ash layers I, II, and III are also present. The pollen diagram was given by Auer (1956, fig. 188; 1958, fig. 70, pl. X) ; diatom stratigraphy was published by Frenguelli (1953). Sample no. 2; coll. 1952 and subm. by Väinö Auer, Helsinki University. Comment: the date agrees with those from Rio Negro (Y-196, $7120 \pm 70$, this paper) and from Groenvlei, South Africa (Y-466, 6870 \pm 160 , this paper) in showing that the rising sea of postglacial time approached the present level at the time of the Boreal-Atlantic transition. However, there is a conflict with the volcanic-ash chronology, in that layer $\mathrm{O}_{2}$ is older than layer I, dated at Estancia Pirinaica (Y-183-I, 11,680 \pm 150 ) and at Altos Boqueron (Y-188, Y-189, average $9140 \pm 90$, this paper). Peat buried below sealevel in coastal swamps is always suspect.

\section{Estancia Pirinaica series, Tierra del Fuego}

Peat from various levels in a bog at Estancia Pirinaica $\left(54^{\circ} 17^{\prime} \mathrm{S}\right.$ Lat, $66^{\circ} 47^{\prime} \mathrm{W}$ Long), Tierra del Fuego, Argentina. Volcanic-ash layers I, II, and III, dated as "postglacial" because they lie within zones dominated by pollen of southern rainforest species and overlie steppe-pollen zones, are preserved in the bog, the oldest (I) at $2.3 \mathrm{~m}$. The pollen diagram (Auer, 1958, locality T 66) is similar to that for the upper part of the section at La Mision (Auer, 1956, fig. 188; 1958, fig. 70; see Y-181, this paper). Coll. 1952 and subm. by Väinö Auer, Helsinki University.

\section{Y-183-I. Estancia Pirinaica 4}

$11,680 \pm 150$

Coll. by Hiller peat-sampler at $2.3 \mathrm{~m}$, near volcanic-ash layer I. Sample no. 4. Comment: because of the way it was collected, and because the postglacial marine transgression nearly reached and may have disturbed this level, the sample is believed to be less reliable than Y-188 $(8905 \pm 110)$ as a date for ash layer I. As in northwestern Europe and northeastern North America, postglacial afforestation should have begun about 9000 or 10,000 в.P.

Y-183-II. Estancia Pirinaica 5- $\quad 6600 \pm 90$

Coll. by spade from 0 to $3 \mathrm{~cm}$ below volcanic-ash layer II. Sample no. 5-.

\section{Y-183-III. Estancia Pirinaica 5+ $4480 \pm 50$}

Coll. by spade from 0 to $3 \mathrm{~cm}$ above volcanic-ash layer II. Sample no. $5+$. Comment: this ash layer, like its supposed equivalents throughout southern South America, lies in or just below a pollen zone recording a brief return of steppe conditions (Auer, 1950, 1953, 1956, 1958), and has therefore been correlated with early Sub-Boreal layers in Europe. This correlation seems unlikely, in view of the substantially older dates of the peat immediately underlying the ash (Y-182, $6690 \pm 100$; Y-183-II, $6600 \pm 90$, this paper), but it is not in conflict with the date of Y-183-III. Closer spacing of radiocarbon samples, considered impracticable in 1952, is obviously desirable.

\section{Y-183-IV. Estancia Pirinaica 6}

$2240 \pm 60$

Coll. by spade at volcanic-ash layer III. Sample no. 6. Comment: this layer was dated as early Sub-Atlantic by Auer on the evidence of pollen zonation, which shows steppe conditions followed by Nothofagus forest without rainforest species; the date is in excellent agreement. 
Average: $9140 \pm 90$

Peat from below and above volcanic-ash layer I, which lies at $7.4 \mathrm{~m}$ in a bog at Altos Boqueron (53 $17^{\prime} \mathrm{S}$ Lat, $69^{\circ} 57^{\prime} \mathrm{W}$ Long), Tierra del Fuego, Argentina. The pollen diagram (Auer, 1958, locality T 34) refers to a profile, made in 1929, that proved to be incomplete downward, and does not show ash layer I. Coll. 1952 and subm. by Väinö Auer, Helsinki University.

Y-188. Altos Boqueron 11-

$8905 \pm 110$

Slightly humified Drepanocladus peat, coll. with spade from 0 to $5 \mathrm{~cm}$ below ash layer I.

Y-189. Altos Boqueron $11+$

$9380 \pm 90$

Decayed Marsippospermum peat, coll. with spade from 0 to $5 \mathrm{~cm}$ above ash layer I. Comment: the two dates are not significantly different, and have heen averaged. See Estancia Pirinaica series for discussion.

\section{Y-182. Rio Ewan, Tierra del Fuego $\quad 6690 \pm 100$}

Carex peat from 0 to $5 \mathrm{~cm}$ below volcanic-ash layer II (second youngest) in a bog at Rio Ewan (54. 19' S Lat, $67^{\circ} 22^{\prime} \mathrm{W}$ Long), Tierra del Fuego, Argentina. The pollen diagram has been published by Auer (1958, locality T 63). Sample no. 3; coll. 1952 and subm. by Väinö Auer, Helsinki University. Comment: the date agrees with that of Y-183-II, $6600 \pm 90$ (this paper), for the peat below ash layer II at Estancia Pirinaica.

Y-192. Lago Espejo, Argentina $\quad 2720 \pm 60$

Charcoal from between volcanic-ash layers $0_{1}$ and $0_{2}$, exposed in a soil profile at Lago Espejo ( $40^{\circ} 38^{\prime} \mathrm{S}$ Lat, $71^{\circ} 46^{\prime} \mathrm{W}$ Long), Lago Nahuel Huapi district, Argentina. The ash layers were described petrologically by Salmi (1941) and dated by Auer (1950) by reference to their pollen-stratigraphic position in a bog at Bariloche, regarded by Auer (1948, 1950, 1953) as typical for the region. Layers $0_{1}$ and $0_{2}$ antedate the oldest layer (I) at Bariloche, however, and were regarded as "late-glacial" for this reason. These layers are also missing from the published pollen diagram from Lago Espejo (Auer, 1958, locality P 7). Sample no. 14; coll. 1952 by Adria Crotti de Ubeda Molina and Mrs. Joly Lagisquet de López Alaniz; subm. by Väinö Auer, Helsinki University. Comment: the ash layers all lie close to the surface, as shown in Auer's photograph (Salmi, 1941, fig. 3; republished, with revised stratigraphic designations, by Auer, 1950, fig. 13). The date may be explained by contamination by modern humus or tree-roots.

\section{Y-193. Lago Todos los Santos, Chile}

Modern

Nothofagus dombeyi from a stump at $4 \mathrm{~m}$ depth, part of a drowned forest rooted in situ at depths as great as $12 \mathrm{~m}$ below the modern level of Lago Todos los Santos, near Puerto Varas ( $41^{\circ} 25^{\prime} \mathrm{S}$ Lat, $72^{\circ} 40^{\prime} \mathrm{W}$ Long), Chile. Auer (1950, p. 202, figs. 95, 105) believed the lake to have been formed by a lava flow related to the eruption of volcanic-ash layer 0 in the Nahuel Hupai district of Argentina; an ash layer that was assumed to be layer 0 has been eroded by the rising lake, hence the forest was inferred to be of "late-glacial" age. Coll. 1952 by Federico Reichert; subm. by Väinö Auer, Helsinki University. Comment: the date casts some doubt on the correctness of the correlation of ash layers during Auer's reconnaissance of the Chilean slope; the 
correlations are not supported by pollen stratigraphy, as they are in Tierra del Fuego. The sample was not collected by Auer himself, however, and may not date the drowned forest that he described.

\section{Rio Negro series, Argentina}

Peat and swamp clay, covered by alluvium and lying below modern sealevel in the estuary of Rio Negro, $13 \mathrm{~km} \mathrm{~W}$ of Viedma $\left(40^{\circ} 45^{\prime} \mathrm{S}\right.$ Lat, $62^{\circ} 40^{\prime}$ W Long), Argentina. The deposits were described by Auer (1952) as recording two episodes of rising sealevel in postglacial time, the older probably of Yoldia age, the younger of Ancylus-Littorina age, separated by an episode of lower sealevel during which the peat was formed; both marine transgressions were believed to have reached levels above the modern one. The new section, coll. 1952 (Auer, 1952, p. 461), shows no deposits that are demonstrably marine, but supports the inference that the postglacial sea rose to within a few meters of the modern level, stabilized or fell, and rose again. Coll. 1952, with Hiller peat sampler, and subm. by Väinö Auer, Helsinki University.

Y-196. Rio Negro $17 \quad 7120 \pm 70$

Swamp clay from $5.8 \mathrm{~m}$ below high-tide level. Auer's sample 17.

\section{Y-198. Rio Negro 19}

$6555 \pm 130$

Scirpus peat from 4.8 to $4.6 \mathrm{~m}$ below high-tide level, in a layer that grades downward into swamp clay at about $5.6 \mathrm{~m}$ and is overlain by swamp clay, and then by red clay and by alluvium. Auer's sample 19.

\section{Y-197. Rio Negro 18}

$6570 \pm 110$

Swamp clay from $4.0 \mathrm{~m}$ below high-tide level, in the upper of two swampclay bodies. Auer's sample 18. Comment: the three samples are of approximately the same age, that of the Boreal-Atlantic transition. Auer's inference that the peat should be of Ancylus age is confirmed; see Y-466 and Y-467 (this paper) for a South African sequence with similar implications.

\section{Australia}

\section{Rottnest Island series, Western Australia}

Mollusc and barnacle shells collected from a sequence of well-marked littoral terraces associated with raised beach deposits on Rottnest Island $\left(32^{\circ} 00^{\prime}\right.$ $\mathrm{S}$ Lat, $115^{\circ} 33^{\prime} \mathrm{E}$ Long, off the coast of Western Australia. The geology was described by Teichert (1950). The dates of these shells, like that of Y.324, from Point Peron, are calculated on the assumption that modern carbonate contains $5 \%$ more $\mathrm{C}^{14}$ than does modern wood. Coll. 1955 and subm. hy R. W. Fairbridge, Columbia Universily, New York.

Y-332. Rottnest, 5-ft level, barnacles

Barnacle shells adhering to tip of visor of older limestone, $8 \mathrm{ft}$ above low. tide level and $8 \mathrm{ft}$ above floor of Government House Lake. As the harnacles are intertidal animals, they are assumed to represent the 5 to 6 - $\mathrm{ft}$ sealevel. Comment: this date must be rejected, as the sample incorporated a portion of the older limestone substratum. The predicted age was ca. $2000 \mathrm{yr}$.

Y-333. Rottnest, 5-ft level, pelecypods

$5180 \pm 100$

Pelecypod (Barbatia pistachia) shells, found in a pocket of rock adjacent 
to Y-332. The species is sessile and lives in the intertidal zone. Comment: although care was taken to exclude fragments of the older limestone substratum, this sample also is older than the expected $2000 \mathrm{yr}$, and may have incorporated some older carbon by chemical means.

Y-337. Rottnest, 10-ft level

$3810 \pm 90$

Large pelecypod shells, mostly Katelysia scalarina, from shell bank $15 \mathrm{ft}$ above low-tide level (and lake floor), on S side of Lake Baghdad, $100 \mathrm{yd}$ NW of Mt. Herschel. Collected near outside (seaward) edge of raised-beach sequence and regarded as dating the end of the (?Atlantic) period when sealevel was $10 \mathrm{ft}$ above present. Comment: the date corresponds closely to prediction for "younger Peron Terrace" (Fairbridge, 1958).

Y-324. Point Peron, 10-ft beach

$5120 \pm 130$

Selected, clean shells (mostly Katelysia scalarina) from a shell bank $16 \mathrm{ft}$ above present low-tide level, Point Peron $\left(32^{\circ} 16^{\prime} \mathrm{S}\right.$ Lat, $115^{\circ} 42^{\prime} \mathrm{E}$ Long, Western Australia. The bank, marked "24-ft shell beds" on map by Fairbridge (1950, opp. p. 72), is correlated with a raised beach ( 10 to $24 \mathrm{ft}$ alt.) resting on a littoral terrace formed when sealevel was $10 \mathrm{ft}$ above present level. The sample was taken close to former cliff and thus should date an early stage in the period of high sealevel, the predicted age of which was ca. 4000 B.P. Coll. 1955 and subm. by R. W. Fairbridge, Columbia University, New York. Comment: wood correlated with the $10-\mathrm{ft}$ sealevel in Victoria was dated as W-170, $4820 \pm 200$ (USGS II). Other dates of this stage, all closer to $4000 \mathrm{yr}$, are: NZ-13, $4600 \pm 70$, from Rapahoe (NZ II); W-443, 3710 \pm 250 , from Queensland (USGS IV) ; C-669, $3479 \pm 200$, from Saipan (Chicago III); L-241B, $3990 \pm 200$, from Algeria (Broecker, unpublished). This earlier phase or 10-ft sealevel has been referred to as "older Peron Terrace" (Fairbridge, 1958).

Y-326. Pinjarra, fluvial terrace "A"

$7030 \pm 90$

Lignitized wood buried in alluvium of "Oakley Terrace", $14 \mathrm{ft}$ above lowtide level and $8.5 \mathrm{mi}$ from sea, exposed in bank of Oakley Brook, tributary of Murray River, near Pinjarra $\left(32^{\circ} 26^{\prime} \mathrm{S}\right.$ Lat, $115^{\circ} 53^{\prime} \mathrm{E}$ Long), Western Australia. The terrace was regarded by the collector as "early Recent". Coll. 1955 by W. M. McArthur; subm. by R. W. Fairbridge, Columbia University, New York. Comment (by Fairbridge) : appears to correspond to "early Atlantice" period of high rainfall in warm-temperate latitudes. In Victoria, Maribyrnong River flooded 12 to $15 \mathrm{ft}$ higher than now, according to Gill (1955), who cited charcoal (W-169,8500 \pm 250 , USGS II) from the Keilor terrace.

Y-327. Pinjarra, fluvial terrace " $B$ "

$5680 \pm 120$

Lignitized wood buried in alluvium of "Marrinup level", $20 \mathrm{ft}$ above lowtide level, exposed in bank of Oakley Brook at the same location as Y-326. The terrace was regarded by the collector as "mid-Recent". Coll. 1955 by W. M. McArthur; subm. by R. W. Fairbridge, Columbia University, New York. Comment (by Fairbridge) : appears to correspond to continued pluvial conditions leading up to mid-Recent high-sealevel stage. Dates rate of fluvial sedimenta- 
tion here as ca. $1 \mathrm{ft}$ in $230 \mathrm{yr}$ or $1.3 \mathrm{~mm} / \mathrm{yr}$ (probably under thalassostatic control).

\section{E. Miscellaneous}

\section{Y-444. Tawau, North Borneo}

Wood, imbedded in alluvium containing volcanic ash and overlain by basalt of the youngest lava flow of the region, Balung-Apas area near Tawau $\left(4^{\circ} 20^{\prime} \mathrm{N} \mathrm{Lat}, 118^{\circ} 05^{\prime} \mathrm{E}\right.$ Long), British North Borneo. The alluvium is lateritized, and the age of the sample should date the episode of weathering that preceded the volcanism, which is believed (Fitch, 1954) to be of Pleistocene age. Valuable agricultural soils are developed on the basalt, and in the absence of more direct evidence of the age of the volcanism, the date of the underlying alluvium should provide estimates of rates of soil-forming and soil-alteration processes. Coll. by T. R. Paton; subm. 1956 by F. M. Fitch, Geological Survey of Borneo, Jesselton, North Borneo. Comment: as the sample is of "infinite" age, its date is of little help in settling either the age of the volcanism or that of the soils.

\section{Abulat Island series, Red Sea}

Coral and shell from 10 to $15 \mathrm{~m}$ altitude on emerged reef, interior of Abulat Island ( $19^{\circ} 58^{\prime} \mathrm{N}$ Lat, $40^{\circ} 07^{\prime} \mathrm{E}$ Long), on Farsan Bank, off the Arabian coast of the Red Sea. The island (Nesteroff, 1955) is of composite structure, consisting of a Pleistocene reef, emergence of which is probably related to the latest important movements on the lines of regional faulting, surrounded by modern fringing and barrier reefs. The latest movements of sealevel are believed to have been eustatic, and are recorded by notches and small platforms cut in the reef rock at 1.2 to $1.4 \mathrm{~m}$ and at 2.4 to $2.8 \mathrm{~m}$ above mean low-tide level. The older, tectonic, emergence, to ca. $30 \mathrm{~m}$ above sealevel, was so recent, judging from the freshness of coral and shell at 10 to $15 \mathrm{~m}$ altitude, that it was thought accessible to radiocarbon dating. Coll. 1951 and subm. by W. D. Nesteroff.

\section{Y-423. Modern shell}

$1130 \pm 80$

Chlamys (?) shell from living molluscs, coll. by the Calypso expedition. Comment: these modern shells, used to provide a reference standard for the dated carbonate samples below, proved to have a significant apparent age. The mean $\mathrm{C}^{14}$ content was 0.923 times that of the reference wood standard, which is 110 years old, i.e. the shells were $7.7+1.4$ percent poorer in $\mathrm{C}^{14}$ than contemporary wood, instead of being 5 percent richer. The total anomaly, 14.1 percent, indicates a fictitious age of $1130 \mathrm{yr}$. The $\mathrm{C}^{13}$ content, +1.84 , per mil above the reference (limestone) standard, indicates that isotopic fractionation is not responsible for the anomaly. Sea water as old as this is not likely to have been brought to the surface by upwelling in this region, though upwelling may be a contributory cause. Evidence that the "Suess effect" (dilution of the modern atmosphere by industrial carbon; Suess, 1955) can account for most or all of the anomaly will be published elsewhere. The uncorrected $\mathrm{C}^{14}$ assay, 0.923 times 110-yr-old wood, has been used to calculate the dates of older Abulat Island samples. 
Y.419. Abulat Island, M.R. 110

$24,730 \pm 2500$

Coral from ca. $10 \mathrm{~m}$ altitude; station M.R. 110.

Y-420. Abulat Island, M.R. 112, coral

Coral from ca. $15 \mathrm{~m}$ altitude, on summit of small conical hill; station M.R. 112.

Y-422. Abulat Island, M.R. 112, shell

Fossil shells from same station as Y-420.

Y.421. Abulat Island, M.R. 113

Coral from ca. $10 \mathrm{~m}$ altitude; station M.R. 113. Comment: in view of the anomalous $\mathrm{C}^{14}$ assay of the modern shells, one finite date (Y-419) in four attempts to date these carbonate samples cannot be regarded as beyond question; the sample may have been slightly contaminated, or all four samples may have an age which is finite but close to the limits of radiocarbon dating. The implication is that the emergence of the old reef is of late Pleistocene age, as expected; the eustatic movements, which may be of the same age as those recorded in Australia (see Y-324 and comment on related samples), are not dated by any samples in the Abulat Island series.

\section{Groenvlei series, South Africa}

Peat and gyttja from fen deposits at Groenvlei $\left(33^{\circ} 48^{\prime} \mathrm{S} \mathrm{Lat}, 22^{\circ} 52^{\prime} \mathrm{E}\right.$ Long), a coastal lagoon in the Knysna Division, South Africa. Borings (Martin, 1956) show marine mud intercalated in the freshwater deposits, beginning at $5.8 \mathrm{~m}$ below the surface of the fen (ca. $3 \mathrm{~m}$ below mean sealevel), and grading upward into brackish-water and then to freshwater deposits. Brackish-water diatoms have their maximum at $3.6 \mathrm{~m}$ below the fen surface, and a fully freshwater diatom assemblage was re-established at $1.7 \mathrm{~m}$. Pollen analysis shows that heath vegetation predominated from the beginning of deposition until the return to freshwater conditions commenced. Coll. 1956 and subm. by A. R. H. Martin, Botany School, University of Sydney, Sydney, Australia.

\section{Y-466. Groenvlei, lower freshwater layer}

$6870 \pm 160$

Humified freshwater peat from $310-\mathrm{cm}$ portions of a $30 . \mathrm{cm}$ core, coll. by Hiller borer immediately below the level of marine mud at $5.8 \mathrm{~m}$ below the fen surface.

\section{Y.467. Groenvlei, upper freshwater layer}

$1905 \pm 60$

Gyttja from $2.9 \mathrm{~m}$ below the fen surface, overlying marine and brackishwater deposits; coll. by post-hole auger. Comment: the marine incursion, which seems never to have reached a higher level than today's, is bracketed between the age of the Boreal-Atlantic transition and the beginning of Sub-Atlantic time in Europe.

\section{Y-529. Vigo, Spain}

Charcoal from $6.67 \mathrm{~m}$ below modern bottom, water depth $13 \mathrm{~m}$, in boring $3 \mathrm{y}$, Vigo harbor $\left(42^{\circ} 14^{\prime} \mathrm{N}\right.$ Lat, $5^{\circ} 04^{\prime} \mathrm{W}$ Long $)$, Spain. The charcoal came from a lacustrine deposit, containing carbonized higher-plant remains but no diatoms or pollen, overlain by sand and then by postglacial marine mud. Inferred age (by correlation with borings J2 and J3: Margalef, 1956) late-glacial 
or Boreal. Coll. by Obras del Puerto Franco de Vigo; subm. by Ramón Margalef, University of Barcelona. Comment: in borings J2 and J3 the supposed correlative of this lacustrine deposit is a fossil soil, found below depths of 25.5 to $29 \mathrm{~m}$ below present sealevel and overlain by marine sediments recording the postglacial rise of sealevel. The sealevel was inferred to have reached $-25 \mathrm{~m}$ by Boreal time (Margalef, 1956). Although the postglacial segments of the three borings are clearly correlated with each other, as shown by Margalef's unpublished work on boring $3 \mathrm{y}$, the underlying soils in borings $\mathrm{J} 2$ and $\mathrm{J} 3$ are undated and may not be contemporaneous with the lacustrine deposits underlying boring $3 \mathrm{y}$. If they are contemporaneous, the land surface that was drowned is much older than late-glacial.

\section{Y-573. St. Vincent, British West Indies}

$4090 \pm 50$

Charred $\log , 3$ to 4 in. in diam, found within the lower $6 \mathrm{ft}$ of a 20 - to 25-ft layer of andesitic tuff-breccia, exposed along $\mathrm{N}$ bank of Rabaka River ca. $3 / 8 \mathrm{mi}$ inland from mouth of river ( $13^{\circ} 17^{\prime} 45^{\prime \prime} \mathrm{N}$ Lat, $61^{\circ} 07^{\prime} 45^{\prime \prime} \mathrm{W}$ Long), St. Vincent, British West Indies. Stratigraphic evidence (Hay, 1958) indicates that this tuff-breccia is one of the lower units of a long prehistoric sequence of glowing-avalanche deposits, resembling in composition that erupted in A.D. 1902. Coll. 1957 and subm. by R. L. Hay, University of California, Berkeley. Comment: there is evidence that the dominant wind direction during accumulation of ash underlying the dated tuff-breccia was westerly or northwesterly, rather than easterly as at present, but the time of the inferred shift in wind direction is not closely dated by the sample.

\section{ARCHAEOLOGIC SAMPLES \\ A. Eastern North America}

\section{Lagoon Pond series, Oak Bluffs, Massachusetts}

Charcoal associated with artifacts in the Lagoon Pond site $\left(41^{\circ} 26^{\prime} \mathrm{N}\right.$ Lat, $70^{\circ} 36^{\prime} \mathrm{W}$ Long), near Oak Bluffs, Martha's Vineyard, Massachusetts. The site has been excavated entirely by amateurs; systematic removal, in numbered squares, was carried out in an area of $490 \mathrm{ft}^{2}$ by E. G. Huntington, with records of supposed culture layers above sterile soil as follows: yellow earth, thickness 0 to more than 30 in.; brown earth, thickness 0 to more than 40 in.; shell, thickness 0 to more than 36 in.; sterile topsoil, thickness 0 to more than 36 in. Artifacts were chiefly of stone, entirely so in the lower layers. No evidence of agriculture was encountered, though high ground above the site, which is at the head of a coastal lagoon, would have been suitable for agriculture, and forest disturbance of early date is recorded in unpublished pollen diagrams obtained from Martha's Vineyard by J. G. Ogden III. Coll. 1957 by E. G. Huntington; subm. by Irving Rouse, Yale University, who has summarized the stratigraphy in an unpublished memorandum.

Y-582. Lagoon Pond, ceramic $1030 \pm 70$

Charcoal from bottom of shell layer, square M4. Probably Point Peninsula (Woodland) culture. Comment: the date is certainly too young for the Point Peninsula culture, which has been dated several times (e.g. M-194, $2180 \pm$ 300, Michigan I; C-192, $2948 \pm 170$, Chicago I). 
Y-583. Lagoon Pond, preceramic

$1430 \pm 60$

Charcoal from near bottom of culture layer, square 07. Preceramic, probably Archaic culture. Comment: this sample also is much younger than expected. The culture is comparable to that at the Wopanucket site on the adjacent mainland (M-764, 4250 \pm 300 , unpublished).

\section{Y-459. Frontenac Island, New York}

$3970 \pm 80$

Charcoal from a hearth of Frontenac (middle Archaic) culture at Frontenac Island $\left(42^{\circ} 50^{\prime} 30^{\prime \prime} \mathrm{N}\right.$ Lat, $76^{\circ} 42^{\prime} 30^{\prime \prime} \mathrm{W}$ Long), Cayuga Lake, Cayuga County, New York, immediately overlying bedrock. The site was described by Ritchie (1945). Coll. 1953 and subm. by W. A. Ritchie, New York State Museum, Albany. Comment: a similar sample (C-191, 4930 \pm 260 , Chicago I) has been quoted (e.g. Flint and Deevey, 1951) as providing a minimum date for the draining of Lake Iroquois, a correlative of Lake Algonquin III. The new sample was originally expected to be slightly older on archaeologic grounds, but restudy of the artifacts shows that it was not, and its date does not affect the dating of Lake Iroquois.

\section{Rohr Shelter series, West Virginia}

Charcoal from Rohr Shelter (39 $35^{\prime} \mathrm{N}$ Lat, $79^{\circ} 50^{\prime} \mathrm{W}$ Long), Monongalia County, West Virginia. The samples span the history of Archaic culture at the site, where it is represented by the lower two-thirds of the deposit, overlain by pottery-bearing layers. The underlying yellow sand is interpreted as fluviatile, laid down when Bee Run Creek, now many feet below the shelter, was cutting the rock formation in which the shelter is found. Coll. 1955 and subm. by D. W. Dragoo and Albert Bauer, Carnegie Museum, Pittsburgh 13, Pennsylvania.

\section{Y.484. Rohr Shelter, late Archaic}

$2200 \pm 60$

From hearth in block A3, 18 in., sample 46Mg9.C1, in transition zone from late Archaic to early Woodland.

\section{Y.485. Rohr Shelter, middle Archaic}

$1940 \pm 70$

From hearth in block A3, 24 to 26 in., sample 46Mg9-C2, about midway in Archaic deposit; the cultural materials are similar to those of Laurentian culture in New York State.

\section{Y-486. Rohr Shelter, early Archaic}

$5310 \pm 90$

From hearth in block A2, 32 to 36 in., sample 46Mg9-C3, just above sterile yellow sand; the artifacts are typologically early Archaic. Comment: the difference between the ages of Y-484 and Y-485 is nonsignificant. The three samples give a satisfactory dating of Archaic Laurentian culture in the upper Ohio valley, from its inception through its transition to the potterymaking Early Woodland culture.

\section{B. Middle America}

\section{Y.437. Tlalpam, Mexico}

$1925 \pm 60$

Carbonized bark, imbedded in alluvium ca. $10 \mathrm{in.} \mathrm{below} \mathrm{the} \mathrm{lava} \mathrm{flow}$ from Xitle Volcano, at Tlalpam (19 $19^{\circ} \mathrm{N}$ Lat, $99^{\circ} 11^{\prime} \mathrm{W}$ Long), Distrito Federal, Mexico. The same lava bed surrounds the base of the pre-Classic 
stone structure at Cuicuilco, ca. $1000 \mathrm{ft}$ away (Cummings, 1933); artifacts of the Ticoman phase have been found at the same stratigraphic position as the bark at several sites (Vaillant, 1935). Coll. 1956 and subm. by Hans Lenz, Villa Obregon, Mexico 20, D. F. Comment: the date agrees with that of M-663 $(2040 \pm 200$, Michigan III) for charcoal in the (Ticoman?) culture layer underlying the lava at the Peña Pobre quarry; the date of another specimen (M-664, $1430 \pm 200$, Michigan III) is not acceptable. The Chicago date for Cuicuilco charcoal (C-200, $2422 \pm 250$, Chicago I) is also in agreement.

\section{Kaminaljuyu series, Guatemala}

Charcoal and wood from the archaeologic zone of Kaminaljuyu (14. $38^{\prime}$ $\mathrm{N}$ Lat, $90^{\circ} 32^{\prime} \mathrm{W}$ Long), near Guatemala, Guatemala. A long series of Highland Maya cultures, ranging from earliest pre-Classic through Classic, has been excavated at the site (Kidder and others, 1946; Shook and Kidder, 1952). The following table shows the sequence for highland Guatemala, as established by archaeologists of the Carnegie Institution of Washington, with dates estimated hefore the advent of radiocarbon dating (Shook, 1952):

$\begin{array}{llr}\text { Post-Classic } & \text { Chinautla } & 1200-1525 \text { A.D. } \\ \text { Classic (late) } & \text { Ayampuc } & 900-1200 \text { A.D. } \\ & \text { Pamplona } & 800-900 \text { A.D. } \\ \text { Classic (early) } & \text { Amatle } & 500-800 \text { AD. } \\ & \text { Esperanza } & 300-500 \text { A.D. } \\ \text { Pre-Classic } & \text { Aurora } & 200-300 \text { A.D. } \\ & \text { Santa Clara } & 0-200 \text { A.D. } \\ & \text { Arenal } & 500-0 \text { B.C. } \\ & \text { Miraflores } & 1000-500 \text { B.c. } \\ & \text { Providencia-Sacatepequez } & 1500-1000 \text { B.C. } \\ & \text { Majadas } & 1600-1500 \text { B.C. } \\ & \text { Arevalo } & 1800-1600 \text { B.C. } \\ & \text { Las Charcas } & 2000-1800 \text { B.c. }\end{array}$

The samples, which were charcoal unless designated otherwise, were coll. at various times, and subm. by Carnegie Institution of Washington (H. E. D. Pollock).

Y-384. Kaminaljuyu, Las Charcas phase

$\mathbf{2 3 4 0} \pm \mathbf{5 0}$

From pit no. 1, Finca Las Charcas, ca. $1 \mathrm{~km} \mathrm{~S}$ of SW edge of Kaminaljuyu. Accompanied by human, animal, and bird bones, by carbonized seeds, and by pottery of late Las Charcas style. Sample no. 18; coll. 1950 by E. M. Shook. Comment: the Las Charcas phase is placed by this date as roughly equivalent to Zacatenco in highland Mexico, which has given a date of $2450 \pm$ 250 (M-662, Michigan III). A Chicago date for Zacatenco (C-196, $3310 \pm$ 250 , Chicago I) now seems too old by a significant margin, as does an unpublished Chicago date, C-885, $3500 \pm 800$, for another portion of Y-384.

Y-401. Kaminaljuyu, Arevalo phase

$2240 \pm 60$

From general fill of second structure in mound C.III-10. Sample no. 39; Coll. 1951 by E. M. Shook. 
Y-402. Kaminaljuyu, Arevalo phase

$\mathbf{2 0 7 0} \pm \mathbf{5 0}$

From top of sandy layer directly overlying sterile soil, outside base of primary and sealed by second structure, mound C-III-10. Sample no. 40; coll. 1952 by A. V. Kidder. Comment: Y-402 is stratigraphically older than Y-401, and its slightly younger $\mathrm{C}^{1+}$ age, in comparison to that of $\mathrm{Y}-401$, is not significant.

Y-390. Kaminaljuyu, Majadas phase

$\mathbf{2 3 3 5} \pm \mathbf{5 0}$

From intrusive cache in mound C-III-6. Sample no. 26; coll. 1951 by E. M. Shook. Comment: a Chicago date (C-886? published as C-884, $2970 \pm 200$, Chicago V), for another portion of this specimen, seems to be slightly too old. The number C-884 is given to two samples in Chicago V, one of which is the Miraflores specimen reported below as Y-382. Cross-reference under C-891 implies that the correct number of the Majadas sample is C-886.

\section{Y-370. Kaminaljuyu, Providencia phase}

$1850 \pm 60$

Wood post from SW post-hole in mound D-III-10, associated with the older of two main periods of construction; fill sherds date the mound as belonging to the Providencia phase. Sample no. 4; coll. 1949 by E. M. Shook. Comment: this date may be slightly too young, judging by the placement of the Providencia phase between Majadas and Miraflores phases, and by the date of Y-374 (2120 \pm 60$)$ from the supposedly contemporaneous Sacatepequez culture. An unpublished Chicago date, C-879, 3130 \pm 300 , for another portion of $\mathrm{Y}-370$, however, is certainly too old.

\section{Y-377. Kaminaljuyu, Miraflores phase $1940 \pm 60$}

From tomb 1, mound E-III-3 (Shook and Kidder, 1952). Sample no. 11; coll. 1949 by E. M. Shook.

\section{Y-382. Kaminaljuyu, Miraflores phase $\quad 1920 \pm 60$}

From fill of structures $3 \mathrm{~b}, 3 \mathrm{c}, 3 \mathrm{~d}$, and 4, mound E-III-3. Sample no. 16; coll. 1950 by E. M. Shook. Comment: the Chicago date (C-884, 3142 \pm 240 , Chicago V) for another portion of this specimen is clearly too old.

Y-391. Kaminaljuyu, Miraflores phase

From fill of structure 5, mound E-III-3. Sample no. 27; coll. 1951 by E. M. Shook. Comment: the Chicago date (C-887, $2490 \pm 300$, Chicago V) for another portion of this specimen can now be seen to be slightly too old. Miraflores time was an age of astonishingly ambitious building at Kaminaljuyu, and the agreement of the three essentially identical dates with those for the culturally similar Cuicuilco phase in Mexico (Y-437, $1925 \pm 60$ ) is striking. Kidder and others (1946) believed that the great buildings at Teotihuacan will prove also to have heen begun in pre-Classic time.

Y.406. Kaminaljuyu, Santa Clara phase $\quad 1800 \pm 60$

From midden sealed by terrace fill of structure D-III-1. Sample no. 44; coll. 1952 by E. M. Shook. Comment: this sample dates the terminal phase of the pre-Classic sequence at Kaminaljuyu. If there was a real cultural break between pre-Classic and Classic, it came just after the end of the Santa Clara phase. 
From grave 1, mound D-III-13 (Berlin, 1952). Sample no. 12; coll. 1949 by E. M. Shook.

Y-396. Kaminaljuyu, Aurora phase

$1860 \pm 60$

From bottom of post-hole in fill of structure associated with floor 2 and 3 , earlier than stone-stairway structure $\mathrm{N}$, and later than painted-adobe structure M, mound D-III-13. Sample no. 33; coll. 1951 by Heinrich Berlin.

Y-405. Kaminaljuyu, Aurora phase

$1660 \pm 60$

From burned post, upright in post-hole, in fill of an adobe structure below the oldest identified one (structure K), mound D-III-13. Sample no. 43; coll. 1952 by Heinrich Berlin. Comment: Sample Y-405 is the oldest of the three on archaeologic grounds and gave the youngest date, but the discrepancies are not significant.

Y-629. Kaminaljuyu, Aurora phase

$1560 \pm 70$

From below burial and above stones, mound D-III-13. The charcoal was oven-dried immediately after excavation. Coll. 1958 by Michael and Sophie Coe; subm. by Gordon Willey, Harvard University, through Irving Rouse. Comment: this sample, which should be nearly contemporaneous with Y.396, was measured as a check on the possibility that Shook's samples from Kaminaljuyu might have suffered contamination by mold during storage in Guatemala. For the Aurora phase, at least, the date shows that no serious discrepancies resulted from storage. Restudy of older samples is none the less desirable; for many Middle American pre-Classic dates, Libby's solid-carbon measurements made in 1951-1954 range from slightly to significantly older than gas-counting figures obtained more recently. In addition to five samples from Kaminaljuyu reported here (Y-384, Y-390, Y-370, Y-382, Y-391), discrepancies are apparent in dates for Zacatenco (C-196, $3310 \pm 250$, Chicago I; M-662, $2450 \pm 250$, Michigan III) and Tlatilco (C-199, 3407 \pm 250 , and C-198, 6390 \pm 300 , Chicago I; M-660, $2525 \pm 250$, Michigan III) in the Valley of Mexico. The impression that the errors are systematic is probably an illusion, however; numerous rechecks have shown that many solid-carbon dates (but relatively few of Chicago's) are too young, presumably owing to radioactive contamination, while other errors are small and random as to direction.

\section{Y-374. Zacat, Sacatepequez phase}

$2120 \pm 60$

Charcoal from pit R-3, Zacat, Sacatepequez (14. $43^{\prime} \mathrm{N}$ Lat, $90^{\circ} 39^{\prime} \mathrm{W}$ Long), Dept. of Sacatepequez, Guatemala. Sherd lot R-3, pure Sacatepequez phase. Sample no. 8; coll. 1949 by E. M. Shook; subm. by Carnegie Institution of Washington. Comment: The Sacatepequez pre-Classic culture is considered a western variant of Providencia, dated $1850 \pm 60$ at Kaminaljuyu (Y-370). Although the difference is small and probably nonsignificant, the date of Y-374. fits the sequence better.

\section{Lowland Maya series}

Wood from various sites in Guatemala and Yucatan, subm. by Carnegie Institution of Washington as a continuation of the Kaminaljuyu series. 
Sapote beam from vault, W end of room 8, structure A-XVIII, Uaxactun ( $17^{\circ} 24^{\prime} \mathrm{N}$ Lat, $89^{\circ} 38^{\prime} \mathrm{W}$ Long), Dept. Peten, Guatemala. The building belongs to the early Classic Tzakol phase. Sample no. 1; coll. 1950 by R. E. Smith. Comment: the date is in notable agreement with St-162, $1720 \pm 65$ (Stockholm I) for the early Classic phases II-III of Teotihuacan, Mexico, crossdated by the occurrence of imported Tzakol pottery (Linné, 1956).

Y-368. Uaxactun, Tepeu phase

$1330 \pm 70$

Logwood lintel from doorway between rooms 36 and 54 , structure A-V, Uaxactun ( $17^{\circ} 24^{\prime} \mathrm{N}$ Lat, $89^{\circ} 38^{\prime} \mathrm{W}$ Long), Dept. Peten, Guatemala. This part of structure A-V was built during the late Classic Tepeu phase (Smith, 1950) probably after 9.15.0.0.0 (A.D. 730, by Goodman-Martinez-Thompson correlation). Sample no. 2 ; coll. 1950 by R. E. Smith.

Y-392. Tikal

Logwood beam from structure 60 , Tikal $\left(17^{\circ} 14^{\prime} \mathrm{N}\right.$ Lat, $89^{\circ} 38^{\prime} \mathrm{W}$ Long), Dept. Peten, Guatemala. The structure was built during late Classic time. Sample no. 29; coll. 1951 by Stephen Borhegyi. Comment: for discussion of Maya dates, including closely dated samples from Tikal, see General comment at end of Lowland Maya series.

Y-369. Nebaj

$770 \pm 60$

Wood beam from tomb VIII, mound 2, Nebaj $\left(15^{\circ} 24^{\prime} \mathrm{N}\right.$ Lat, $91^{\circ} 09^{\prime} \mathrm{W}$ Long), Dept. Quiche, Guatemala. The structure belongs to the early post-Classic (Tohil plumbate) period (Smith and Kidder, 1951). Sample no. 3; coll. 1947 by A. L. Smith.

Y-393. Tulum

$880 \pm 60$

Sapote wood lintel from doorway between rooms D and E, structure 21, Tulum ( $20^{\circ} 15^{\prime}$ N Lat, $87^{\circ} 28^{\prime}$ W Long), Quintana Roo, Mexico. The structure was built late in post-Classic time (Lothrop, 1924). Sample no. 30; coll. 1951 by E. M. Shook.

\section{Y-383. Zacualpa, Late Pokom phase}

$1180 \pm 60$

Fatty pine post from post-hole 3 , structure C-III, Zacualpa $\left(15^{\circ} 02^{\prime} \mathrm{N}\right.$ Lat, $90^{\circ} 47^{\prime}$ W Long), Dept. Quiche, Guatemala. Specimen 2289, (Field no. Z-289), National Museum of Guatemala; pub. by Wauchope (1948, p. 77-80, pl. 10C). The structure belongs to the late post-Classic period of the League of Mayapan. Sample no. 17; coll. 1936 by Robert Wauchope.

Y-627. Uxmal

$\mathbf{1 3 9 0} \pm \mathbf{5 0}$

Wood, presumably sapote, from inner lintel of doorway of room $\mathrm{S}$ of central room in lower $\mathrm{W}$ range of the Adivino, Uxmal $\left(20^{\circ} 26^{\prime} \mathrm{N}\right.$ Lat, $89^{\circ} 46^{\prime}$ W Long), Yucatan, Mexico. Sample no. N. 49; coll. 1958 by Alberto Ruz. Comment: one other date from Uxmal, the most famous of late-Classic northern Yucatan sites, has been published: Gro-613, $1065 \pm 100$, Groningen II).

Y-626. Chichen Itza

$1160 \pm 70$

Wood, presumably sapote, from beam inside $\mathrm{S}$ doorway of temple build. ing (El Castillo), Chichen Itza $\left(20^{\circ} 41^{\prime} \mathrm{N}\right.$ Lat, $88^{\circ} 34^{\prime} \mathrm{W}$ Long), Yucatan, 
Mexico. Sample no. N. 48; coll. 1958 by Alberto Ruz. Comment: El Castillo belongs to the early post-Classic period of Mexican (Toltec) dominance at Chichen. General comment: The pre-Classic development in the Maya area seems to have begun a little later and lasted for a somewhat shorter time than was previously believed, partly on general grounds and partly as a result of a group of Chicago solid-carbon measurements that now seem to have been too old. The Kaminaljuyu series is completely consistent, both internally and at points where external correlation is possible, as between Miraflores and Cuicuilco and between Aurora and Tzakol, and Teotihuacan II-III. Attention should also be called to the long and consistent series of dates from La Venta, Tabasco (Michigan II; see also Drucker and others, 1957), showing pre-Classic construction phases I-IV there lasting from ca. 800 to ca. 400 B.c.

For the Classic and post-Classic periods the sequence in the Peten and in Yucatan has long been well understood, and only the absolute dates have been at issue. Three lintels from Tikal, all bearing the carved date 9.15.10.0.0, have been dated with exceptional care in order to provide a critical comparison between the Maya and Christian calendars (L-113, 1470 \pm 120 , Lamont I; C-948, C-949, average $1503 \pm 110$, Chicago V). These measurements seemed to confirm the Spinden correlation and disprove the Goodman-Martinez-Thompson correlation, heretofore accepted by the Carnegie Institution of Washington and underlying the dates listed in the introduction to the Kaminaljuyu series. Sample Y-392 from Tikal and Y-369 from Nebaj may be slightly too young, and sample Y-383 from Zacualpa may be slightly too old, but the general agreement between the new dates and the pre-radiocarbon estimates for Classic and later phases is noteworthy. The difference between the two correlations, 260 years, is small, corresponding to about 3 percent difference in net $\mathrm{C}^{14}$ content, and methodologic errors of this order of magnitude are inherent in any radiocarbon measurement. We therefore regard the question of Maya-Christian correlation as still an open one.

\section{Y-125. Venado Beach, Canal Zone}

$1750 \pm 60$

Charcoal from Area A, Trench 8, between A-7 and B-2, 29 in. deep, under S edge of urn-cache 5 , Venado Beach, near Fort Kobbe $\left(8^{\circ} 54^{\prime}\right.$ N Lat, $79^{\circ} 37^{\prime}$ W Long), Canal Zone. The excavated grave is one of many that were cut into a layer of coquina, which itself contains sherds of an older culture; local sealevel has fallen since the coquina was formed, but the geologic relations are unclear and the archaeology is understood only for the polychrome-pottery period of occupation (Lothrop, unpublished). Coll. 1951 and subm. by S. K. Lothrop, Peabody Museum, Harvard University. Comment: the implication of so early a date for the latest culture at the site is that the Central American polychrome-pottery complexes were independently developed during the period of the later pre-classic Maya, and were not diffused from the north. The several wares that are dated here form part of the evidence for a complicated pattern of trade between the high cultures of South and North America; Quimbaya gold was widely distributed by this trade, and its manufacture (in Colombia) is evidently much older than could be demonstrated heretofore.

Y-585. Monagrillo, Panama

Charcoal from a small ash lens at the $4090 \pm 70$ 
Lat, $80^{\circ} 28^{\prime} \mathrm{W}$ Long), Herrera Province, Panama. The ceramic but probably pre-agricultural culture was described by Willey and McGimsey (1954). Coll. 1952 and subm. by G. R. Willey, Peabody Museum, Harvard University; his sample no. 52.28.20/19361. Comment: this date agrees much better with current conceptions of Panamanian and nuclear American archaeology than does M-11 (800 \pm 250 , Michigan I), based on marine shells found in the refuse from Willey's 1949 excavation at the site. Three unpublished USGS dates from the Barlovento site in northern Colombia confirm its approximate contemporaneity with Monagrillo.

\section{Y-458-d. Cerro Mangote, Panama}

$6810 \pm 110$

Charcoal from Pit V, 130 to $145 \mathrm{~cm}$ below surface, Stratum C, at the preceramic site of Cerro Mangote (Co-40) $\left(8^{\circ} 18^{\prime} \mathrm{N}\right.$ Lat, $80^{\circ} 41^{\prime} \mathrm{W}$ Long) Coclé Province, Panama. The preceramic culture, identical with the nonceramic content of the ceramic culture of Monagrillo, was described by McGimsey (1956) on the basis of 1955 excavations. The sample was obtained during new excavations in 1956. The various strata recognized are remains of food animals; Stratum C, the latest over much of the site, is almost exclusively composed of crab (Menippe frontalis) shells. Although the site is now $10 \mathrm{~km}$ from the sea, there is evidence (Willey and McGimsey, 1954) that the shoreline has retreated from the region by many $\mathrm{km}$ since Monagrillo time (ca. 4090 B.P.: see Y-585) as a result of lagoon filling. Coll. 1956 by C. R. McGimsey III (his sample no. 696A), University of Arkansas, Fayetteville. Comment: this date was expected to be older than that from the nearby site of Monagrillo, where the culture differs from Cerro Mangote chiefly in carrying pottery, but is in turn the oldest ceramic culture yet known from Panama. Other samples submitted, including those from Stratum A, the initial (mainly oyster) layer, were too small for measurement.

Y-454. Mirinday, Venezuela

$\mathbf{5 8 0} \pm \mathbf{5 0}$

Charcoal from the Mirinday site at Carache $\left(9^{\circ} 37^{\prime} \mathrm{N}\right.$ Lat, $70^{\circ} 14^{\prime} \mathrm{W}$

Long), Esto. Trujillo, Venezuela, accompanied by pottery of the Mirinday style, belonging to Period IV in Cruxent and Rouse's chronologic sequence (Cruxent and Rouse, 1959, p. 148-151). Coll. 1956 by J. M. Cruxent; subm. by Irving Rouse, Yale University. Comment: the date is in substantial agreement with the one other Period IV date, Y-298, El Morro, $715 \pm 70$ (Yale III).

\section{Y-455. EI Heneal, Venezuela}

$3400 \pm 120$

Charcoal from the shell midden of El Heneal $\left(10^{\circ} 42^{\prime} \mathrm{N}\right.$ Lat, $63^{\circ} 18^{\prime} \mathrm{W}$ Long), at mouth of the Rio Aroa, Esto. Falcon, Venezuela. The accompanying culture, El Heneal, is preceramic, dating from Period I (Cruxent and Rouse, 1959, p. 35-36). Coll. 1956 by J. M. Cruxent; subm. by Irving Rouse, Yale University. Comment: this date, for the west coast of Venezuela, compares nicely with those for Period I sites on the east coast and islands off shore, which range from $3050 \pm 80$ for Y-296g, La Aduana 1 (Yale III) to $4150 \pm 80$ for Y.497, Punta Gorda (this date list). It is somewhat later than the date of $6810 \pm 100$ for Y-485d (this date list), Cerro Mangote, Panama, where several similar types of artifacts are present. Nevertheless, the complete set of 
Period I dates forms a continuous series, extending over a somewhat longer time span than had been anticipated.

\section{Y-456. Pedro Garcia, Venezuela}

Charcoal from a shell midden at the Pedro Garcia site $\left(10^{\circ} 5^{\prime} \mathrm{N}\right.$ Lat, $64^{\circ}$ $51^{\prime}$ W Long), near Barcelona, Esto. Anzoetegui, Venezuela. The accompanying culture, known as Pedro Garcia, is non-ceramic but has trade pottery which permits the site to be dated in Period II (Cruxent and Rouse, 1959, p. 105107). Coll. 1956 by J. M. Cruxent and Irving Rouse, Yale University; subm. by Rouse. Comment: the sample was originally dated in Period IV because of the presence of pottery on the surface of the midden belonging to the Guaraguaro style. The radiocarbon date was too old for this period (cf. Y-454, Mirinday, $580 \pm 50$, this date list). Therefore, Cruxent and Rouse re-excavated the site in 1957 and found that the Period IV pottery was limited to the surface. The radiocarbon sample, which came from the bottom of the midden, is instead to be associated with a non-ceramic complex, as indicated above.

\section{Y-457. Cerro Machado, Venezuela}

$1930 \pm 70$

Charcoal from the Cerro Machado site ( $10^{\circ} 37^{\prime} \mathrm{N}$ Lat, $67^{\circ} \mathrm{1}^{\prime} \mathrm{W}$ Long), at the mouth of the Rio Tacagua, Distrito Federal, Venezuela. The accompany. ing style, Cerro Machado, belongs to Period II in the local sequence. Coll. 1956 by J. M. Cruxent; subm. by Irving Rouse, Yale University. Comment: cf. Tocuyano, M-257, 2180 \pm 300 (Michigan I), which contains a closely related style of pottery, also dated in Period II on the relative time scale. Other Period II dates, for such unrelated styles as El Mayal, Y-297, $1795 \pm 90$ (Yale III)
are also consistent.

\section{Y-465. Vega del Palmar, Cuba}

$960 \pm 60$

Charcoal from the Vega del Palmar site $\left(22^{\circ} 02^{\prime} \mathrm{N}\right.$ Lat, $80^{\circ} 24^{\prime} \mathrm{W}$ Long) at the fork of the Rio Arimao, SW of the Bahia de Cienfuegos, Las Villas province, Cuba; found in the 105- to $120-\mathrm{cm}$ level of a midden, $150 \mathrm{~cm}$ deep, which yielded pottery only in the top two $15-\mathrm{cm}$ levels. The preceramic levels of this deposit date from Period III and the ceramic levels from Period IV in the Caribbean chronology (see Y.454, this date list). Coll. 1956 and subm. by P. G. Hahn, Yale University. Comment: confirms other evidence that preceramic, Ciboney culture survived until Period III (cf. Rouse, 195la, fig. 3).

\section{Y.497. Punta Gorda, Venezuela}

$4150 \pm 80$

Charcoal from the preceramic, Cubagua-complex levels at the base of the Punta Gorda midden, Cubagua Island, eastern Venezuela $\left(10^{\circ} 49^{\prime} \mathrm{N}\right.$ Lat, 64 ${ }^{\circ}$ $9^{\prime} \mathrm{W}$ Long). From Excavation 4, sections $\mathrm{P}$ and Q, 3.5 to $4.0 \mathrm{~m}$. The site is described by Cruxent and Rouse $(1959$, p. 46-49); it contains a succession of three non-ceramic complexes, from hottom to top, as follows: (1) Culagua, without shell gouges, (2) Manicuare complex, with such gouges, and (3) Punta Gorda complex, with gouges and also trade pottery. Complexes (1) and (2) are dated in Period I and complex (3) in Period II on the relative time scale. The sample is associated with complex (1). Coll. 1957 by J. M. Cruxent and Irving Rouse, Yale University; subm. by Rouse. Comment: the earliest date yet obtained for Venezuela. It was expected to be earlier than the two 
Manicuare-complex dates, Y-296g, $3050 \pm 80$ and Y-295, 3570 \pm 130 (Yale III), and it is.

\section{Y-499-2. Los Barrancos, Venezuela}

$1370 \pm 90$

Charcoal from Los Barrancos site $\left(8^{\circ} 43^{\prime} \mathrm{N}\right.$ Lat, $62^{\circ} 10^{\prime} \mathrm{W}$ Long), Esto. Monagas, Venezuela; test pit, 0.50 to $0.75 \mathrm{~m}$, accompanied by pottery of the Los Barrancos style of Period III. Coll. 1956 by J. M. Cruxent and Irving Rouse, Yale University; subm. by Rouse. Comment: this is the type site of the Los Barrancos style (Cruxent and Rouse, 1959, p. 227-230), formerly designated Barrancas 3 in the sequence of pottery styles established at the nearby site of Saladero (Rouse, 1951b, p. 345). The date compares favorably with the other two dates for Period III: $1580 \pm 40$ for Y-290, Irapa (Yale II) and $1355 \pm 80$ for Y-300, El Mayal 1 (Yale III).

\section{Africa}

Y-135-9. Mapungubwe, Transvaal $\mathbf{5 3 0} \pm \mathbf{6 0}$

Charred millet from the Mapungubwe site $\left(22^{\circ} 05^{\prime} \mathrm{S}\right.$ Lat, $29^{\circ} 20^{\prime} \mathrm{E}$ Long), northern Transvaal, South Africa; found at position $6^{\prime} 58^{\prime} 3^{\prime}(3 \mathrm{ft}$ depth) in block 2, strip 4. The site is part of the Zimbabwe complex, and is being described by Gardner. Coll. 1939 by Capt. Guy Gardner; subm. by Phillip Tobias, University of the Witwatersrand, Johannesburg. Comment: see Y-135-17.

Y-135-14. Mapungubwe, Transvaal $\mathbf{5 7 0} \pm \mathbf{6 0}$

Charred millet and wood from a burned hut at the Mapungubwe site $\left(22^{\circ}\right.$ $05^{\prime} \mathrm{S}$ Lat, $29^{\circ} 20^{\prime} \mathrm{E}$ Long), northern Transvaal, South Africa; found at position $35^{\prime} 0^{\prime} 5^{\prime}$ ( $5 \mathrm{ft}$ depth) in block 6, strip 4 (sample A). Coll. 1939 by Capt. Guy Gardner; subm. by Phillip Tobias, University of the Witwatersrand, Johannesburg. Comment: see Y-135-17.

\section{Y-135-17. Bambandyanalo, Transvaal}

$900 \pm 65$

Charcoal accompanying ceremonial beast-burial no. 6 , with 14 pots, at site $\mathrm{K} 2$, near Bambandyanalo Hill $\left(22^{\circ} 05^{\prime} \mathrm{S}\right.$ Lat, $29^{\circ} 20^{\prime} \mathrm{E}$ Long), northern Transvaal, South Africa; found at $5.5 \mathrm{ft}$ depth in blocks 4-6, strip 6, coordinates A-14', R-7'. The pre-Bantu, proto-Hottentot culture is related to the Zimbabwe complex of Southern Rhodesia, and is being monographed by Gardner; skeletal remains are being described by Alex Galloway. Coll. 1938 by Capt. Guy Gardner; subm. by Phillip Tobias, University of the Witwatersrand, Johannesburg. Comment: two lintel-timbers from a relatively old period of construction at Zimbabwe (i.e. older than 14th or 15th century A.D.) have been dated (Summers, 1955) : C-613, $1361 \pm 120$ (Chicago III), and C-917, $1506 \pm 305$ (Chicago V), the latter also measured by the Institute of Geochronology, University of London, as GL-19, $1240 \pm 80$ (London I). The Zimbabwe complex is large, and evidently some of its sites were occupied over many centuries.

\section{REFERENCES}

Date lists:

Chicago I. Arnold and Libby, 1951

Chicago III. Libby, 1952

Chicago V. Libby, 1954 
Groningen II. de Vries, Barendsen, and Waterbolk, 1958

Heidelberg I. Münnich, 1957

Humble II. Brannon and others, 1957

Lamont I. Kulp, Feely, and Tryon, 1951

Lamont II. Kulp and others, 1952

Lamont III. Broecker, Kulp, and Tucek, 1956

Lamont IV. Broecker and Kulp, 1957

London I. Zeuner, 1955

Michigan I. Crane, 1956

Michigan II. Crane and Griffin, 1958a

Michigan III. Crane and Griffin, 1958b

NZ II. Fergusson and Rafter, 1955

Stockholm I. Östlund, 1957

USGS I. Suess, 1954

USGS II. Rubin and Suess, 1955

USGS IV. Rubin and Alexander, 1958

Yale II. Preston, Person, and Deevey, 1955

Yale III Barendsen, Deevey, and Gralenski, 1957

Arnold, J. R., and Libby, W. F., 1951, Radiocarbon dates: Science, v. 113, p. 111-120.

Auer, Väinö, 1948, Las capas volcánicas como nuevo método de cronología postglacial en Fuegopatagonia: Gaea, v. 8, p. 311-336; repr. as: Rep. Argentina, Minist. Agricultura, Inst. Suelos Agrotecnia Pub. 6.

1950, Las capas volcánicas como base de la cronología postglacial de Fuegopatagonia: Rev. Inv. Agr., v. 3, p. 49-208; repr. as: Rep. Argentina, Minist. Agricultura, Inst. Suelos Agrotechnia Pub. 9.

__ 1952, Evolución postglacial del valle inferior del río Negro y varaciones cuaternarias de la línea costanera: Rev. Inv. Agr., v. 5 [1951], p. 425-464.

$61,8 \mathrm{p}$. 1953, Nuevos aspectos de la sequía en la Patagonia: Idia [Buenos Aires], no. 1956, The Pleistocene of Fuego-Patagonia. Part I: The ice and interglacial ages: Acad. Sci. Fennicae Annales, ser. A, III, no. 45, 226 p., 5 pl.

1958, The Pleistocene of Fuego-Patagonia. Part II: The history of the flora and vegetation: Acad. Sci. Fennicae Annales, ser. A, III, no. 50, 239 p., 10 pl.

Barendsen, G. W., Deevey, E. S., and Gralenski, L. J., 1957, Yale natural radiocarbon measurements III: Science, v. 126, p. 908-919.

Berlin, Heinrich, 1952, Excavaciones en Kaminal Juyu: Monticulo D-III-13: Antropología Hist. Guatemala, v. 4, no. 1, p. 3-18.

Brannon, H. R., Jr., and others, 1957, Humble Oil Company radiocarbon dates II: Science, v. 125, p. $919-923$.

Broecker, W. S., and Kulp, J. L., 1957, Lamont natural radiocarbon measurements IV: Science, v. 126, p. 1324-1334.

Broecker, W. S., Kulp, J. L., and Tucek, C. S., 1956, Lamont natural radiocarbon measurements III : Science, v. 124, p. 154-165.

Burns, G. W., 1958, Wisconsin age forests in western Ohio. II. Vegetation and burial conditions: Ohio Jour. Sci., v. 58, p. 220-230.

Cameron, H. L., 1956, Nova Scotia historic sites: Royal Soc. Canada Trans., ser. 3, v. 50, sec. 2 , p. 1-7.

Crane, H. R., 1956, University of Michigan radiocarbon dates I: Science, v. 124, p. 664672.

Crane, H. R., and Griffin, J. B., 1958a, University of Michigan radiocarbon dates II: Science, v. 127, p. 1098-1105. 1123

Cummings, Byron, 1933, Cuicuilco and the Archaic culture of Mexico: Arizona Univ. Bull., v. 4, no. 8; Soc. Sci. Bull. 4, 56 \%.

Cruxent, J. M., and Rouse, Irving, 1959, An archaeological chronology of Venezuela: Pan American Union Soc. Sci. Mon., v. (), 000 p., atlas of 000 figs., 000 pls.

Deevey, E. S., 1948, On the date of the last rise of sea level in southern New England, with remarks on the Grassy Island site: Am. Jour. ScI., v. 246, p. 329-352.

- 1951, Late-glacial and postglacial pollen diagrams from Maine: An. Jour. Scr., v. 249 , p. $177-207$.

1958, Radiocarbon-dated pollen sequences in eastern North America: Geobot. Inst. Rübel, Zürich, Veröffentl., no. 34, p. 30-37.

Douglas, D. L., 1952, Measuring low-level radioactivity: General Electric Rev., v. 55, no. 5 (September), p. 16-20. 
Drucker, P., Heizer, R. F., and Squier, R. J., 1957, Radiocarbon dates from La Venta, Tabasco: Science, v. 126, p. 72-73.

Fairbridge, R. W., 1950, The geology and geomorphology of Point Peron, Western Australia: Royal Soc. Western Australia Jour., v. 34, p. 35-72. Australia: Royal Soc. Western Australia Jour., v. 34, p. 35-72.
1958, Dating the latest movements of the Quaternary sea level: New York Acad. Sci. Trans., ser. 2, v. 20, p. 471-482.

Fergusson, G. J., and Rafter, T. A., 1955, New Zealand ${ }^{14} \mathrm{C}$ age measurements 11 : New Zealand Jour. Sci. and Technology, sec. B, v. 36, p. 371-374.

Fitc F M 1954, The weology and mineral resources of part of the Secama Valley and Darveo Bay Brish Borneo Geol. Survey Mem. 4, p. 49-54.

Flint R F. 1955a, Rates of advance and retreat of the margin of the late-Wisconsin ice sheet: Äm. Jour. ScI., v. 253, p. 249-255. sheet: Am. Jour. Sci., v. 253, p. 1955 b, Pleistocene geology of eastern South Dakota: U. S. Geol. Survey Prof. Paper 262, $173 \mathrm{p}$.

Flint R. F and Deevey, E. S., 1951, Radiocarbon dating of late-Pleistocene events: Aм. Jour. ScI., v. 249, p. 257-300.

Flint, R. F., and Gale, W. A., 1958, Stratigraphy and radiocarbon dates at Searles Lake, California: Am. Jour. Sci., v. 256, p. 698-714

Flint, R. F, and Rubin Meyer, 1955, Radiocarbon dates of pre-Mankato events in eastern and central North America. Science, v. 121, p. 649-658.

Frenguelli, Joaquín, 1953, Análisis microscópico de una segunda serie de muestras de la 位ón, Río Grande, Tierra del Fuego: Acad. Sci. Fennicae Annales, ser. A, III, no. 34,52 p.

Gill, E. D. 1955, Radiocarbon dates for Australian archaeological and geological samples: Australian Jour, Sci., v. 18, p. 49-52

Godwin, H Sugrate, R. P., and Willis, E. H., 1958, Radiocarbon dating of the eustatic rise

Goldthwait, R. P. 1958, Wisconsin age forests in western Ohio. I. Age and glacial events: Ohio Jour. Sci., v. 58 , p. 209-219.

Hansen H. P. 1941, Further pollen studies of post Pleistocene bogs in the Puget low, Then, 133-148. land of Washington: Torrey Bot. Club Bull., v. 68, p. 133-148. 1947, Postglacial forest succession, climate, an 1, 130 p.

Hay, R. L., 1958, Crystal-rich glowing-avalanche deposits of St. Vincent, B.W.I. [abs.]: Geol. Soc. America Bull., v. 69, p. 1578-1579.

Jore Boylston Street fishweir: R. S. Peabody Found. Archaeology [Phillips Acad.] Papers, v. 2, xii, 212 p.

Johnson, Frederick, ed., 1949, The Boylston Street fishweir II: R. S. Peabody Found. Archaeology [Phillips Acad.] Papers, v. 4, no. 1, x, 133 p.

Kid A Kaminaljuyu, Guatemala: Carnegie Inst. Washington Pub. 561, ix, 248 p., illus.

Kulp, J. L., Feely, H. W., and Tryon, L. E., 1951, Lamont natural radiocarbon measurements, I: Science, v. 114, p. 565-568.

Kulp 116 , p. 409-414.

Leopold, E. B., 1956, Two late-glacial deposits in southern Connecticut: Nat. Acad. Sci. Proc., v. 42 , p. $863-867$.

Libby, W. F 1952 Chica radiocarbon dates, III: Science, v. 116, p. 673-681.

Libby, W. F., 1952, Chicago radiocarbon dates, I11: Science, ve 116, p. 673-742.

Linné, Sigvald, 1956, Radiocarbon dates in Teotihuacan: Ethnos, 1956, no. 3-4, p. 180-193.

( negie Inst. Washington Pub. 335 , vii, 179 p.

negie Inst. A., and Livingstone, B. G R 1958 , Late-glacial and postglacial vegetation Livingstone, D. A., and Livingstone, B. G. R., 1958, Late-glacial and postan Scotia: Am. Jour.
from Gillis Lake in Richmond County, Cape Breton Island, Nova Scota Sci., v. 256, ю. 341-359.

lon C. J and Goldthwait, J. W. 1934, An attempt to cross-date trees in drowned forests: Geog. Rev., v. 24, \%. 605-614.

Margalef, Ramón, 1956, Paleoecología postglacial de la Ría de Vigo: luv. P'esqueras, v. 5, 1. 89-112.

Martin, A. R. H., 1956, The ecology and history of Grocnvlei: South African Jour. Sci., v. 52 , p. $187-192,198$.

Matin $P$. 1958, Taiga-tundra and the full-glacial period in Chester County, Pennsylvania: Aм. Jour. ScI., v. 256, p. 470-502.

McGimsey, C. R., 1956, Cerro Mangote: a preceramic site in Panama: Am. Antiquity, v. 22 , p. 151-161. 

Münnich, K. O., 1957, Heidelberg natural radiocarbon measurements I: Science, v. 126,
p. 194-199.

Nesteroff, W. D., 1955, Les récifs coralliens du Banc Farsan Nord (Mer Rouge), in: Resultats scientifiques des campagnes de la "Calypso", I. Campagne en Mer Rouge (1951-1952) : Inst. Océanog. [Monaco] Annales, v. 30,53 p., 21 pl.

Östlund, H. G., 1957, Stockholm natural radiocarbon measurements I: Science, v. 126, p. $493-497$.

Preston, R. S., Person, Elaine, and Deevey, E. S., 1955, Yale natural radiocarbon measurements II: Science, v. 122, p. 954-960.

Rigg, G. B., and Gould, H. R., 1957, Age of Glacier Peak eruption and chronology of post-glacial peat deposits in Washington and surrounding areas: Am. Jour. ScI., v.
255 , p. 341-363.

Ritchie, W. A., 1945, An early site in Cayuga County, New York: Rochester Mus. Arts Sci. Res. Rec. 7.

Rouse, Irving, 195la, Areas and periods of culture in the Greater Antilles: Southwestern Jour. Anthropology, v. 7, p. 248-265.

York 1951b, Prehistoric Caribbean culture contact as seen from Venezuela: New York Acad. Sci. Trans., ser. II, v. 13, p. 342-347.

Rubin, Meyer, and Alexander, Corrinne, 1958, U. S. Geological Survey radiocarbon dates IV: Science, v. 127, p. 1476-1487. Rubin, Meyer, and Suess, H. E., 1955, U. S. Geological Survey radiocarbon dates II: Sci-
ence, v. 121, p. 481-488.

Salmi, Martti, 1941, Die postglazialen Eruptionsschichten Patagoniens und Feuerlands: Acad. Sci. Fennicae Annales, ser. A, III, no. 2, 115 p., 2 pl.

Shepard, F. P., and Moore, D. G., 1955, Central Texas coast sedimentation; characteristics of sedimentary environment, recent history, and diagenesis: Am. Assoc. Petroleum
Geologists Bull., v. 39, p. 1463-1593.

Shepard, F. P., and Suess, H. E., 1956, Rate of postglacial rise of sea level: Science, v. 123, p. 1082-1083

Shook, E. M., 1952, Lugares arqueológicos del altiplano meridonal central de Guatemala: Antropología Hist. Guatemala, v. 4, no. 2, p. 3-40.

Shook, E. M., and Kidder, A. V., 1952, Mound E-III-3, Kaminaljuyu, Guatemala: Carnegie Inst. Washington Pub. 596, p. 35-127, 81 figs.

Smith, A. L., 1950, Uaxactun, Guatemala: excavation of 1931-1937: Carnegie Inst. Washington Pub. 588, xi, 108 p., 143 fig.

Smith, A. L., and Kidder, A. V., 1951, Excavations at Nebaj, Guatemala: Carnegie Inst. Washington Pub. 594, vii, 90 p., illus., map.

Suess, H. E., 1954, U. S. Geological Survey radiocarbon dates I: Science, v. 120, p. 467 473.

Summers, Ro55, Radiocarbon concentration in modern wood: Science, v. 122, p. 415-417.

Teichert, Curt, 1950, The dating of the Zimbabwe ruins: Antiquity, v. 29, p. 104-111 Australia: Royal Soc. Victoria Proc., v 59, p. 63-79.

Thwaites, F. T., and Bertrand, Kenneth, v. 59, p. $63-79$.

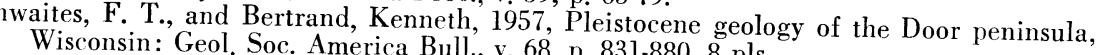

Vaillant, G. C. 1935, Early cultures of the Valley of Mexis. 8 pls.

project of the American Museum of Natural Mexico: results of the stratigraphical project of the American Museum of Natural History in the Valley of Mexico, 19281933: Am. Mus. Nat. History Anthropol. Papers, v. 35, p. 281-328.

Vries, Hl. de, Barendsen, G. W., and Waterbolk, H. T., 1958, Groningen radiocarbon dates II: Science, v. 127, p. 129-137.

Wauchope, Robert, 1948, Excavations at Zacualpa, Guatemala: Tulane Univ. Middle Am. Res. Inst. Pub. 14, 168 p., illus.

Willey, G. R., and McGimsey, C. R., 1954, The Monagrillo culture of Panama: Peabody Mus. Archaeology and Ethnology [Harvard Univ.] Papers, v. 49, xiii, 158 p., 54 figs.

Williams, Stephen, 1957, The Island 35 mastodon: its bearing on the age of Archaic cul tures in the East: Am. Antiquity, v. 22, p. 349-372.

Zeuner, F. E., 1955, Radiocarbon dates: Univ. London Inst. Archaeology 11th Amn. Rept., 